POLIARCHIA

Studencko-doktoranckie czasopismo naukowe

Wydziału Studiów Międzynarodowych i Politycznych UJ nr 2(11)/2018 s. 27-59

ISSN 2300-4584 eISSN 2392-1218

www.poliarchia.wsmip.uj.edu.pl

https://doi.org/10.12797/Poliarchia.06.2018.11.02

\author{
Mateusz NOWAK \\ Uniwersytet Jagielloński \\ m.nowak.krakow@gmail.com
}

\title{
NOWY POPULIZM PENALNY \\ NA PRZYKŁADZIE PRZESTĘPSTW \\ PRZECIWKO WIARYGODNOŚCI FAKTUR
}

ABSTRACT The New Penal Populism as the Example of Crime against the Credibility of Invoices

The article provides an overview of the populist narrative in the legislative process. The author argues that new penal populism affects more and more complicated branches of law, including a tax law. The author conducts a case study, analysing the new crime in the Polish penal code - the crime against credibility invoices. Populist aspects both in the legislation and in the political discourse surrounding it were also discussed.

KEYWORDS penal populism, criminal law, economic crime, VAT, invoice 


\section{WSTĘP}

W literaturze z zakresu nauk o komunikacji społecznej i mediach pisze się o „nowym komunikowaniu politycznym", które rozwinęło się wraz z ekspansją środków masowego przekazu1. Od lat 80 . XX w. ${ }^{2}$ mamy do czynienia z „telepopulizmem”3. Paul Taggart wspomina o "nowym populizmie", który powstał w opozycji do biurokratycznych państw opiekuńczych ${ }^{4}$ oraz partii politycznych pogrążonych $w$ kryzysie ${ }^{5}$. Racjonalna polityka była wypierana również podczas recesji gospodarczych oraz przemian stratyfikacyjnych w społeczeństwie ${ }^{6}$. Punktem wspólnym dla różnych źródeł populizmu była utrata zaufania. Duża część społeczeństwa przestała wierzyć, że porządek instytucjonalny jest w stanie zwalczyć nawarstwiające się problemy. W konsekwencji społeczeństwo negowało rzeczywistość, wyrażając swój sprzeciw

„Nowy populizm” jest zjawiskiem dynamicznym i ciągle rozszerza obszar swojego oddziaływania. Nadal dominują w nim zagadnienia o charakterze światopoglądowym lub kwestie należące do tzw. nurtu feministycznego, jak na przykład aborcja, gwałt oraz seksualnośćs. Jednakże populiści coraz częściej nie ograniczają się wyłącznie do tzw. głośnych spraw dotyczących sfery światopoglądowej. Pod wpływem mediów populizm penalny degeneruje również bardziej złożone dziedziny prawa. Wieloaspektowe regulacje, będące na pograniczu kilku gałęzi prawa, nie zawsze są zrozumiałe dla opinii publicznej, co nie oznacza, że nie są tworzone pod wpływem tendencji demagogicznych. Wręcz przeciwnie. Narracja polityków, na przykład dotycząca gospodarki, jest jeszcze bardziej upraszczana i dostosowywana do przeciętnego odbiorcy, co nie pozostaje bez wpływu na jakość stanowionego prawa. Połączenie populizmu i interdyscyplinarnych regulacji prawnych nie jest nowym zjawiskiem. Natomiast skala tego procesu pozwala przypuszczać, że obserwujemy narastający i wysoce niepokojący trend, który będzie coraz silniej negatywnie oddziaływał na proces legislacyjny.

Istnieje wiele technik mierzenia populizmu'. Dotyczą one głównie holistycznych analiz partii politycznych lub wypowiedzi liderów ugrupowań. W badaniach opar-

B. Dobek-Ostrowska, Podstawy komunikowania spotecznego, Wrocław 1999, s. 128-129.

2 P. Przyłęcki, Populizm w polskiej polityce. Analiza dyskursu polityki, Warszawa 2012, s. 33-35.

3 M. Szafrańska, Penalny populizm a media, Kraków 2015, s. 45.

4 P. Taggart, Populism, Buckingham 2000, s. 75.

5 Tenże, The New Populism and the New Politics. New Protest Parties in Sweden in Comparative Perspective, London 1996, s. 45-46.

6 F. Panizza, Introduction: Populism and the Mirror of Democracy, [w:] Populism and the Mirror of Democracy, red. tenże, London 2005, s. 11-13.

7 H. G. Betz, Radical Right-wing Populism in Western Europe, New York 1994, s. 37-38.

8 C. Boggs, The New Populism and the Limits of Structural Reforms, „Theory and Society” 1983, vol. 12, nr 3, s. 358.

9 Kirk Hawkins zaproponowal, żeby oceniać wypowiedzi polityków w skali od 0 do 2, w oparciu o wcześniej przygotowane kryteria. Zero oznaczało wypowiedź niezawierającą elementów populistycznych. Dwa wskazywało, że przemówienie ma charakter demagogiczny. Z kolei jeden wskazywało na narrację mieszaną. Por. K. A. Hawkins, Is Chaves Populist. Measuring Populist Discourse in Comparative 
tych na studium przypadku ${ }^{10}$ przydatniejsza jest analiza strukturalna $\mathrm{z}$ naciskiem na semiotykę języka. Socjolingwistyczne podejście do języka kładzie nacisk na komunikację i treści zakodowane w przekazie. Semantyka i syntaktyka są nierozerwalne i wspólnie determinują ostateczne znaczenie ${ }^{11}$. Jednostką analizy była wypowiedź uczestnika procesu legislacyjnego na temat popieranych przez niego zmian w prawie karnym ${ }^{12}$. Analizę komunikatów ograniczono do tych, które pojawiły się podczas procedowania projektu. Pominięte zostały wypowiedzi w środkach masowego przekazu. Oprócz opinii uczestników badano także ścieżkę legislacyjną projektu, ze szczególnym uwzględnieniem wpływów populistycznych. W tym kontekście pomocna była metoda dokumentowa oraz analiza treści ${ }^{13}$. Studium przypadku dotyczyło ustanowienia nowych przestępstw przeciwko wiarygodności faktur, zaproponowanych w rządowym projekcie nowelizacji Kodeksu karnego oraz niektórych innych ustaw ${ }^{14}$, a przyjętych w ustawie $\mathrm{z}$ dnia 10 lutego $2017 \mathrm{r}^{15}$

Problem badawczy obejmuje trzy zasadnicze kwestie. Pierwszą z nich było opracowanie uogólnionego modelu populizmu penalnego, w oparciu o najbardziej charakterystyczne cechy. Następnie zbadano nasilenie elementów populistycznych wpływających na proces nowelizacji prawa karnego. Zwrócono uwagę na elementy demagogiczne występujące $\mathrm{w}$ analizowanym przypadku. Ponadto wskazano te, których brakowało. Po trzecie, istotna była końcowa charakterystyka strategii populistycznej. Czy bliżej jej było do „populizmu twardego”, czy może działania miały bardziej „miękkie" właściwości?

Literatura przedmiotu jest bardzo bogata. Wśród ważnych publikacji ostatnich lat należy wyróżnić tę autorstwa Nickie Phillips i Nicholasa Chagnona ${ }^{16}$, którzy badali reakcję amerykańskiej opinii publicznej na zbyt łagodne sankcje karne orzekane przez wymiar sprawiedliwości w sprawach dotyczących przestępstw seksualnych. Mark Fenwick ${ }^{17}$ zwrócił uwagę na postulaty obniżenia wieku, po przekroczeniu któ-

Perspective, „Comparative Political Studies” 2009, vol. 42, nr 8, s. 1047-1051. Dwustopniową skalę zaproponował Matthijs Rooduijn. Por. M. Rooduijn, What Unites the Voter Bases of Populist Parties? Comparing the Electorates of 15 Populist Parties, „European Political Science Review” 2018, vol. 10, nr 3, s. 359. Inną technikę mierzenia, opartą na „grubym” i „cienkim” populizmie, zaprezentowali: Jan Jagers oraz Stefaan Walgrave. Por. J. Jagers, S. Walgrave, Populism as Politicial Communications Style: An Empirical Study of Political Parties' Discourse in Belgium, „European Journal of Political Research” 2007, vol. 46, nr 3, s. 326-333.

10 Zob. E. Babbie, Badania spoteczne w praktyce, przeł. W. Betkiewicz, Warszawa 2004, s. 320.

11 Zob. A. Ferguson, E. Armstrong, Researching Communication Disorders, Basingstoke 2009, s. 7-8.

12 Zob. W. Pisarek, Analiza zawartości prasy, Kraków 1983, s. 43-44.

13 S. Juszczyk, Badania jakościowe w naukach spotecznych. Szkice metodologiczne, Katowice 2013, s. 174-177.

14 Rzadowy projekt ustawy o zmianie ustawy - Kodeks karny oraz niektórych innych ustaw, druk nr 888 z 21 IX 2016 r.

15 Ustawa z dnia 10 lutego 2017 r. o zmianie ustaw - Kodeks karny oraz niektórych ustaw, Dz. U. poz. 244.

16 Zob. N. Phillips, N. Chagnon, „Six Months Is a Joke”: Carceral Feminism and Penal Populism in the Wake of Stanford Sexual Assault Case, „Feminist Criminology” 2018.

17 Zob. M. Fenwick, "Penal Populism” and Penological Change in Contemporary Japan, „Theoretical Criminology" 2013, vol. 17, nr 2, s. 215-231. 
rego nieletni sprawca może ponosić odpowiedzialność karną. James Oleson badał rozwiązanie prawne three-strikes law, które zostało ustanowione po raz pierwszy w Kalifornii ${ }^{18}$. Rollin Tusalem ${ }^{19}$ wskazał na problem wdrożenia kontrowersyjnych programów zwalczania filipińskiej przestępczości zorganizowanej w kontekście naruszeń praw człowieka. W Polsce pojawiają się analizy ustaw dotyczących legalności przerywania ciąży lub aktów penalizujących przestępstwa pedofilskie. Tematykę tę poruszyła Michalina Szafrańska ${ }^{20}$. W innej pracy ta sama autorka ${ }^{21}$ wskazywała na związki populizmu i środków masowego przekazu. Praca zbiorowa pod redakcją Janiny Czapskiej, Michaliny Szafrańskiej i Darii Wójcik 22 jest poświęcona m.in. takim tematom jak zwalczanie korupcji, aktywność seksualna nieletnich i dopuszczalność obrony koniecznej.

\section{CHARAKTERYSTYKA POPULIZMU PENALNEGO}

Populizm jest wszechobecny we współczesnym dyskursie politycznym ${ }^{23}$. Jest nierozerwalnie związany w szczególności z systemami demokratycznymi ${ }^{24}$. Zdaniem Paula Taggarta zdefiniowanie populizmu nie jest proste, ponieważ jest on jak kameleon. Potrafi dostosować się do warunków panujących na danym terytorium i w określonym czasie $^{25}$. Margaret Canovan podkreślała, że populizm może nieść ze sobą różne treści ${ }^{26}$. Argentyński peronizm zrobił z populizmu styl prowadzenia polityki opartej na autorytarnym, charyzmatycznym liderze ${ }^{27}$. W państwach skandynawskich populistyczni politycy krytykowali wysokie obciążenia podatkowe przeznaczone na zbiurokratyzowany system opieki społecznej (m.in. Mogens Glistrup z duńskiej Partii Postępu oraz Bert Karlsson, założyciel szwedzkiej Nowej Demokracji). We Francji Jean-Marie Le Pen,

18 Zob.J. Oleson, Habitual Criminal Legislation in New Zealand: Three Years of Three-strikes, „Australian and New Zealand Journal of Criminology" 2015, vol. 48, nr 2, s. 277-292.

19 Zob. R. Tusalem, Examining the Determinants of Extra-Judicial Killings in the Philippines at the Subnational Level: The Role of Penal Populism and Vertical Accountability, „Human Rights Review” 2018, vol. 19, s. 1-35.

20 Zob. M. Szafrańska, „Kończy się raj dla pedofilów!”. Populizm penalny na przyktadzie ustawy o przeciwdziataniu zagrożeniom przestępczością na tle seksualnym, [w:] Populizm penalny, red. J. Widacki, Kraków 2017, s. 53-77.

21 Zob. M. Szafrańska, Penalny populizm a media, Kraków 2015.

22 Zob. Penalny populizm. Perspektywa polityczna i spoteczna, red. J. Czapska, M. Szafrańska, D. Wójcik, Kraków 2016.

23 P. Taggart, Populism..., s. 115, 119.

24 G. Pasquino, Populizm and Democracy, [w:] Twenty-First Century Populism: The Spectre of Western European Democracy, red. D. Albertazzi, D. McDonnell, Basingstoke 2008, s. 15.

25 P. Taggart, Populism..., s. 115, 119.

26 M. Canovan, Trust the People! Populism and the Two Faces of Democracy, „Political Studies” 1999, vol. 42 , nr 1, s. 4 .

27 P. Taggart, Populism..., s. 66-67, 101. 
lider Frontu Narodowego, żądał zmiany polityki migracyjnej. Podobne postulaty wysuwał Jörg Haider z Austriackiej Partii Wolnościowej. We Włoszech populiści oparli się na różnicach regionalnych. Umberto Bossi, przywódca Ligi Północnej, postulował wsparcie dla południowej części kraju ${ }^{28}$. W XXI w. populizm przybiera na sile. W Europie partie budują swoją pozycję w oparciu o krytykę Unii Europejskiej (UE). Należą do nich ugrupowania prawicowe, m.in.: Partia Niepodległości Zjednoczonego Królestwa ${ }^{29}$ oraz holenderska Partia Wolności ${ }^{30}$. Skoro populizm jest jak kameleon, to funkcjonują również partie lewicowe, które posługują się uproszczoną retoryką. Przykładowo, Syriza wystąiła przeciwko radykalnym cięciom wydatków, które miały uratować pogrążoną w kryzysie Grecję ${ }^{31}$.

Badacze często stawiają sobie pytanie: Czym właściwie jest populizm? Daniele Albertazzi oraz Duncan McDonnell uważali, że był on bez wątpienia ideologią. Według nich mógł być kojarzony zarówno z prawicą, jak i lewicą, co świadczy o płynności populizmu ${ }^{32}$. Podobnie uważał Paul Taggart, zauważając zarazem jego liczne braki, co wpływa na spójność rozumowania ${ }^{33}$ tego zjawiska. Odmienne podejście przyjął Ernesto Laclau. Uważał, że populizm jest uniwersalny i charakterystyczny dla wielu różniących się od siebie ruchów społecznych. Uniemożliwiało to identyfikację populizmu jako ideologii, ponieważ był on „,znaczeniowo pusty”. Można go było traktować jako formę politycznej artykulacji alternatywy dla istniejącego porządku instytucjonalnego ${ }^{34}$. Podejście Laclau jest bliższe prawdzie. Przez swoją niejednoznaczność i uniwersalność populizm powinien być traktowany jako narzędzie lub sposób prowadzenia dyskursu publicznego. Populizm jest bardziej strategią polityczną niż zwartą ideologią.

Populizm można uprościć do jednego, najistotniejszego pojęcia - „ludu”35 lub ewentualnie „milczącej większości” ${ }^{36}$. Populiści wywyższają mądrość społeczeństwa oraz stawiają się w roli egzegetów woli obywateli ${ }^{37}$. Elity, podchodząc lekceważąco do niektórych grup społecznych, budują niechęć do siebie. Powstają napięcia społeczne, które są zręcznie wykorzystywane przez polityków ${ }^{38}$. Ich fundamentalnym zadaniem

28 Tamże, s. 76-84.

29 L. March, Left and Right Populizm Compared: The British Case, „The British Journal of Politics and International Relations" 2017, vol. 19, nr 2, s. 292-294.

30 S. Otjes, T. Louwerse, Populists in Parliament: Comparing Left-Wing and Right-Wing Populism in the Netherlands, „Political Studies” 2015, vol. 63, nr 1, s. 74.

31 C. Mudde, Syriza: The Failure of the Populist Promise, London 2017, s. 10-11.

32 D. Albertazzi, D. McDonnell, Introduction: The Sceptre and the Spectre, [w:] Twenty-First Century Populism. The Spectre of Western European Democracy, red. ciż, Basingstoke 2008, s. 3-6.

33 P. Taggart, Populism..., s. 2.

34 E. Laclau, Populism: What's in a Name?, [w:] Populism and the Mirror of Democracy, red. F. Panizza, London-New York 2005, s. 33-34, 44-47.

35 M. Canovan, Populism for Political Theorist?, „Journal of Politicial Ideologies” 2004, vol. 9, nr 3, s. 342.

36 P. Taggart, Populism..., s. 95.

37 M. Szafrańska, Penalny..., s. 35.

38 J. Pratt, Penal Populism. Key Ideas in Criminology, Abingdon 2007, s. 9-10. 
staje się utrzymanie poparcia społecznego lub powiększenie elektoratu. Populiści ukrywają swoje prawdziwe zamiary, pokazując na każdym kroku, że najważniejszy jest interes publiczny ${ }^{39}$.

Populiści penalni najskuteczniej działają w atmosferze powszechnego strachu. Za pomocą mediów kreowane jest poczucie zagrożenia. Pojedynczy przypadek kryminalny (tzw. głośna sprawa) jest wielokrotnie powtarzany, aby społeczeństwo doszło do wniosku, że ten proceder występuje na porządku dziennym. W ten sposób powstaje tzw. fala przestępczości ${ }^{40}$. Reakcją na pojedyncze przestępstwo jest masowa panika lub przynajmniej spotęgowany niepokój opinii publicznej. Obywatele oczekują natychmiastowych zmian. W tym momencie do działania mogą przystąpić populiści. Dokonują tzw. administrowania strachem. Na początku narracja polityków jest ograniczona do mediów, w których krytykują obecny porządek legislacyjny i wytykają liczne zaniedbania poprzedników. Następnie proponują oni proste metody zmierzające do „naprawy” złych przepisów. Dokonywana jest zmiana prawa, a przez to również ewolucja polityki kryminalnej. Ostatnim etapem jest reakcja społeczeństwa, które najczęściej dokonuje afirmacji nowego podejścia ${ }^{41}$. Charakterystykę populizmu penalnego można więc ograniczyć do wzajemnego oddziaływania na siebie trzech członów, czyli triady: mediów, polityków oraz opinii publicznej ${ }^{42}$.

Punktem wyjścia do niniejszych badań powinno być opracowanie charakterystycznych cech populizmu penalnego. Należą do nich cechy wspólne dla wszystkich odmian populizmu, jak i te, które są specyficzne wyłącznie dla penalnej demagogii. Powracając do postulatu wiary w naturalną mądrość społeczeństwa, należy pokreślić, że populiści dążą do konfrontacji. Zestawiają ze sobą dwie antagonistyczne grupy, co prowadzi do powstania antynomii społecznej. Pierwszą z dychotomicznych zbiorowości jest lud - dobry, skrzywdzony i wrażliwy na wszechogarniające poczucie zagrożenia. Lud odczuwa deficyt sprawiedliwości i pragnie skutecznych rozwiązań prawnych gwarantujących efektywną obronę przed kryminalistami ${ }^{43}$. Demagodzy podkreślają suwerenność społeczeństwa ${ }^{44}$ oraz kreują wizję, w której wszyscy jego członkowie są jednością bez względu na swoje partykularne interesy ${ }^{45}$. Mówią, że wspólne „wygrywanie” w drobnych sprawach budzi nadzieję na lepsze jutro ${ }^{46}$.

39 J. Widacki, Zamiast wstęu. Czym jest i do czego stuży populizm penalny, [w:] Populizm penalny, red. tenże, Kraków 2017, s. 9.

K. Witkowska-Rozpara, Przestępczość, środki masowego przekazu a polityka karna, Warszawa 2011, s. 245.

J. Widacki, Zamiast..., s. 11.

42 M. Szafrańska, „Kończy się raj dla pedofilów!”..., s. 55.

43 M. Szafrańska, Penalny..., s. 47-48.

44 D. Albertazzi, D. McDonnell, Introduction..., s. 6.

45 F. Panizza, Introduction..., s. 9.

46 M. E. Kann, The New Populism and The New Marxism: A Response to Carl Boggs, „Theory and Society” 1983, vol. 12, nr 3, s. 365 . 
Drugim gremium jest elita, która sprawuje władzę. Jest zła, bierna i niewrażliwa na ludzki $\operatorname{los}^{47}$. Co więcej, wspiera wyłącznie interesy „nadreprezentowanej mniejszości” ${ }^{48}$. Populiści wykorzystują "teorie spiskowe”, aby w większym stopniu demonizować wszelkie zachowania klasy rządzącej i wzmacniać asymetrię pomiędzy strukturami ${ }^{49}$. Demagodzy namawiają społeczeństwo, aby wybrać: „alternatywę”, „trzecią drogę”, „demokrację bezpartyjną" "50. Jeśli zostaną namaszczeni przez społeczeństwo, odwrócą hierarchię. Od tej pory „mityczny” lud stanie na pierwszym miejscu, a władza będzie realizować jego postulaty ${ }^{51}$.

Politycy starają się pozorować, że prowadzą debatę publiczną. Nieodzownym elementem dyskusji są emocje takie jak gniew, oburzenie, strach $^{52}$. Populiści, przekazując swój punkt widzenia, korzystają z badań opinii publicznej. Szczególnie pomocne są sondaże, które wykorzystuje się do manipulowania nastrojami społecznymi. Stają się ostatecznym dowodem na to, że dany dyskutant ma w sporze rację ${ }^{53}$. Podobną rolę pełnią postulaty demokracji bezpośredniej. Populiści, odwołując się do „mądrości ludu”, żądają przeprowadzenia referendum, konsultacji społecznych, rozszerzenia obywatelskiej inicjatywy ustawodawczej. Popularne są również listy poparcia, na przykład dotyczące zaostrzania kar, zwłaszcza po tragicznych w skutkach wydarzeniach ${ }^{54}$.

Nie mają racji ci naukowcy, którzy twierdzą, że populiści stronią od ekspertów. Jednakże ich wiedza jest wykorzystywana instrumentalnie. Jeśli dany pogląd jest korzystny dla demagogów - chętnie powtarzają go i przywołują autora (zwłaszcza z tytułem naukowym lub sprawującego prominentne stanowisko) w polemikach. Natomiast w odmiennej sytuacji opinia specjalistów jest przemilczana, a na piedestał powracają badania opinii publicznej lub wrodzona intuicja obywateli ${ }^{55}$. Przydatnym rozwiązaniem okazuje się również pozorne przyznanie racji ekspertowi. W rzeczywistości rozmówca podtrzymuje swoje stanowisko („słuszne w teorii, niesłuszne w praktyce”) ${ }^{56}$. Do debat na temat przestępczości zapraszani są „zwykli ludzie”. Angażuje się telewidzów lub słuchaczy radiowych, aby wyrazili swoje zdanie na temat polityki kryminalnej lub zadali pytanie ekspertowi ${ }^{57}$.

47 M. Szafrańska, Penalny..., s. 47-48.

48 P. Taggart, Populism..., s. 121.

49 Tamże, s. 106.

50 C. Mouffe, The "End of Politics" and the Challenge of Right-wing Populism, [w:] Populism and the Mirror of Democracy, red. F. Panizza, London 2005, s. 54.

51 M. Szafrańska, Penalny..., s. 47-48.

52 E. Plebanek, O polskim populizmie penalnym $w$ zwiazku $z$ obywatelskim projektem nowelizacji ustawy o planowaniu rodziny, ochronie ptodu ludzkiego i warunkach dopuszczalności przerywania ciązy oraz kodeksu karnego z 2016 r., [w:] Populizm penalny, red. J. Widacki, Kraków 2017, s. 18-19.

53 M. Szafrańska, Penalny..., s. 36-37.

54 J. Rybicka, Populizm penalny $w$ dyskursie politycznym, [w:] Penalny populizm..., red. J. Czapska, M. Szafrańska, D. Wójcik, Kraków 2016, s. 58.

55 M. Szafrańska, Penalny..., s. 36-37.

56 Tamże, s. 59.

57 J. Pratt, Penal..., s. 79-81. 
Populiści stale nawiązują do wspomnianej mądrości ludowej. Podkreślają, że są przeciętnymi obywatelami w służbie społeczeństwa. Działają pod popularnym hasłem: „jestem jednym z was”. Dystans pomiędzy władzą a resztą obywateli skraca język debaty publicznej oparty na mowie potocznej, uproszczeniach, a nawet wulgaryzmach ${ }^{58}$. Politycy przejmuja narrację stosowana przez media typu tabloidowego ${ }^{59}$. Wykorzystują slogany, czyli krótkie informacje, łatwo zapadające w pamięć odbiorcy („państwo mafijne”, „przestępczość zorganizowana”). Proponując konkretne rozwiązania, odpowiednio nazywają swój program skierowany do społeczeństwa („zero tolerancji”). Przydatne są także aluzje, które mają na celu dezawuować oponenta politycznego, podawać w wątpliwość jego kwalifikacje, autentyczność, pozycję i dorobek zawodowy („wszyscy to wiemy, panie pośle"). Ataki koncertują się również na przeszłości rozmówcy, powiązaniach z określonymi środowiskami, podważaniu niezależności. Obok bezpośredniego przekazu pojawią się ironiczne uwagi. Powszechnie stosuje się również: metafory (przedstawianie przestępców seksualnych jako „bestii”), hiperbole („mega afera”), epitety („zwyrodniały przestępca”). Słowa te często pojawiają się w nagłówkach artykułów lub w paskach telewizyjnych. Mówcy używają również metonimii, która polega na zastąpieniu danej nazwy innym pojęciem, co gwarantuje szybsze porozumiewanie się. $\mathrm{Na}$ przykład, mówiąc o Pruszkowie, mamy na myśli członków zorganizowanej grupy przestępczej powiązanych z tym miastem. Do innych popularnych środków stylistycznych należą: eufemizmy („mijać się z prawdą”), związki frazeologiczne („prawa ręka”, „prawo pięści”) oraz apostrofy („Szanowni Państwo!” ${ }^{60}$. Oprócz wykorzystania mowy potocznej politycy występują publicznie jako „ikony mediów”. Organizują efektowne konferencje prasowe z rekwizytami lub interaktywnymi materiałami ${ }^{61}$.

Kluczowa jest siła reakcji na dany problem. Demagodzy sięgają do punitywnych rozwiązań, postulując wysoki poziom represyjności. Dominują zwolennicy retrybucyjnych kar izolacyjnych lub kary śmierci. Populiści utrzymują, że dobrym pomysłem są sankcje zawstydzające lub stygmatyzujące (na przykład noszenie specjalnego ubrania podczas wykonywania karnych prac społecznych lub publikacja wizerunku sprawcy przestępstwa). Krytykowani są krzewiciele łagodnych sankcji oraz popularyzatorzy wyroków zawierających elementy restytucyjne ${ }^{62}$.

Populiści dopuszczają nawet dalszą izolację, już po odbyciu zasądzonej kary ${ }^{63}$. Ponadto żądają ograniczania praw skazanych. Uważają oni, że kara pozbawienia wolność nie jest w dostatecznie dotkliwa dla sprawców. W więzieniach panują zbliżone warunki do tych na zewnątrz. Zdaniem demagogów musi się to natychmiast

58 M. Szafrańska, Penalny..., s. 54-55.

59 Ł. Ostrowski, Tak kończq bandyci: obraz kary kryminalnej w publikacjach dziennika „Fakt”, [w:] Kulturowe uwarunkowania polityki kryminalnej, red. M. Filar, J. Utrat-Milecki, Warszawa 2014, s. 127-153.

60 P. Przyłęcki, Populizm w polskiej polityce..., Warszawa 2012, s. 104-106.

${ }_{61}$ G. Mazzoleni, Populism and the Media, [w:] Twenty-First Century Populism. The Spectre of Western European Democracy, red. D. Albertazzi, D. McDonnell, Basingstoke 2008, s. 56-57.

62 J. Pratt, Penal..., s. 24-31.

63 Tamże, s. 29. 
zmienić ${ }^{64}$. Co więcej, pojawia się przekonanie o omnipotencji prawa karnego. Polega ono na przeświadczeniu, iż prawo karne jest „lekiem na całe zło”, a inne środki (na przykład prawo administracyjne, cywilne) są wysoce nieskuteczne $e^{65}$.

Populiści podkreślają wysoką podatność wiktymizacyjną wszystkich obywateli. Każdy może stać się ofiarą przestępstwa. W przekazie pojawiają się skrzywdzona ofiara, zdemoralizowany sprawca i brutalny czyn. Demagodzy uważają, że państwo nie zwraca uwagi na ofiary przestępstw. Co więcej, twierdzą, że to przestępca jest faworyzowany, a poszkodowany nie ma realnej możliwości obrony przed niesprawiedliwością ${ }^{66}$.

Populiści nie zwracają uwagi na konsekwencje swoich projektów. W szczególności dotyczy to restrykcyjnej polityki penitencjarnej. Nadmiernie stosowane kary izolacyjne wiążą się z koniecznością zagwarantowania odpowiednich źródeł finansowania jednostek penitencjarnych. Oprócz utrzymania więźniów dochodzą wydatki związane z zapewnieniem odpowiedniej liczby miejsc dla skazanych, czyli inwestowanie w infrastrukturę więzienną ${ }^{67}$. Pomijają fachową wiedzę nie tylko w debatach publicznych, ale co gorsza, również w procesie legislacyjnym. Marginalizuje się rolę ciał doradczych: komisji kodyfikacyjnych, specjalnych zespołów eksperckich, opinii zewnętrznych autorytetów w danej dziedzinie. Zdarza się, że konsultanci są wybierani tendencyjnie, w oparciu o wyznawane poglądy. Ponadto populiści lekceważąco podchodzą do argumentów pojawiających się podczas posiedzeń komisji sejmowych ${ }^{68}$.

\section{NOWY POPULIZM PENALNY NA PRZYKŁADZIE PRZESTĘPSTWA PRZECIWKO WIARYGODNOŚCI FAKTUR}

\subsection{Charakterystyka nowelizacji ustawy - Kodeks karny}

Od 1 marca 2017 r. w Polsce obowiązują przepisy wprowadzające do kodeksu karnego nowe przestępstwa przeciwko wiarygodności faktur. Pierwsze z nich polega na podrobieniu lub przerobieniu faktury (art. $115 \$ 14$ a k.k.), w celu jej użycia jako autentycznego dokumentu księgowego (art. 270a $\$ 1$ k.k.) ${ }^{69}$. Nielegalna modyfikacja obecnej lub sfałszowanie nowej faktury ma związek z należnościami publicznoprawnymi. Innymi słowy, sprawca za pomocą faktury może starać się o zaniżenie zobowiązania podatkowego lub zawyżenie zwrotu daniny ${ }^{70}$. Drugie przestępstwo fakturowe zostało

\footnotetext{
Tamże, s. 74.

Tamże, 24-31.

M. Szafrańska, Penalny..., s. 55, 142.

J. Pratt, Penal..., s. 150.

M. Szafrańska, Penalny..., s. 154.

Ustawa z dnia 6 czerwca 1997 r. - Kodeks karny, Dz.U. 1997 nr 88 poz. 553, art. 270a $\$ 1$.

70 A. Lach, Komentarz do art. 270(a) Kodeksu karnego, [w:] Kodeks Karny. Komentarz, red. V. Wrzosek-Konarska, A. Lach, J. Lachowski, [online] http://lex.adm.uj.edu.pl/lex/index.rpc?\&fromHistory=false\#content.rpc?nro=201337380\&wersja $=-1$ \&localNroPart $=587773775,8$ I 2019.
} 
Tabela 1. System kategorii przekazu populistycznego

\begin{tabular}{|c|c|}
\hline \multicolumn{2}{|c|}{ A. Cechy wspólne dla różnych odmian populizmu } \\
\hline \multirow{6}{*}{ Lud (W1) } & a. Podkreślanie mądrości ludu \\
\hline & b. Przypominanie o suwerenności ludu \\
\hline & c. Zwrócenie uwagi na jedność społeczeństwa \\
\hline & d. Podkreślanie wspólnej tożsamości z ludem \\
\hline & e. Budowanie antynomii społecznej (antyelitaryzm) \\
\hline & $\begin{array}{l}\text { f. Budowa narracji opartej na docenieniu dotychczas lekceważonej } \\
\text { „milczącej większości” }\end{array}$ \\
\hline \multirow{5}{*}{ Debata Publiczna (W2) } & a. Administrowanie strachem \\
\hline & b. Język potoczny i specyficzne środki stylistyczne \\
\hline & c. Dezawuowanie oponentów politycznych \\
\hline & d. Marginalizowanie wiedzy eksperckiej \\
\hline & e. Manipulowanie badaniami naukowymi \\
\hline \multirow{2}{*}{ Proces legislacyjny (W3) } & a. Rezygnacja z prac ciał doradczych i konsultacji społecznych \\
\hline & b. Lekceważenie opinii prawnych \\
\hline Konsekwencje ustawy(W4) & a. Deprecjonowanie skutków ustawy \\
\hline \multicolumn{2}{|r|}{ B. Cechy typowe dla populizmu penalnego } \\
\hline \multirow{2}{*}{ Prawo karne (W5) } & a. Wysoka punitywność \\
\hline & b. Omnipotencja prawa karnego \\
\hline \multirow{4}{*}{ Ofiara i sprawca (W6) } & a. Mit wysokiej przestępczości \\
\hline & b. Wysoka podatność wiktymizacyjna \\
\hline & c. Zorientowanie na ofiarę \\
\hline & d. Stygmatyzacja sprawcy przestępstwa \\
\hline
\end{tabular}

Źródło: opracowanie własne na podstawie: M. Szafrańska, Penalny populizm a media, Kraków 2015, s. 36 i n.; J. Pratt, Penal Populizm. Key Ideas in Criminology, Abingdon 2007, s. 8 i nast.; P. Przyłęcki, Populizm w polskiej polityce. Analiza dyskursu polityki, Warszawa 2012, s. 104-106. 
uregulowane w art. 271a $\$ 1$ k.k. ${ }^{71}$ Ustawodawca zdecydował się odrębnie penalizować czyn polegający na wystawieniu faktury (lub faktur), której wartość wynosi powyżej 200 tys. zł („znaczna wartość, zgodnie z art. $115 \$ 5$ k.k.), a jej treść jest niezgodna ze stanem rzeczywistym. Podobnie jak w przypadku art. 270a $\$ 1$ k.k., nieprawdziwe informacje zawarte w fakturze mają znaczenie dla określenia należności publicznoprawnej lub uzyskania odpowiedniego zwrotu przez sprawcę. Priorytetem mają być kary stricte izolacyjne, w postaci zagrożenia karą pozbawienia wolności od 6 miesięcy do 8 lat (art. 270a $\$ 1$ k.k. oraz art. $271 \mathrm{a} \$ 1$ k.k.).

Ponadto ustawodawca przewidział czyny charakteryzujące się wyższym stopniem naganności zachowania sprawcy i tym samym powodujące większe straty dla budżetu państwa. Pierwszy z nich dotyczy tzw. przypadków większej wagi (art. 270a $\$ 2$ k.k. ${ }^{72}$ oraz art. 271a $\$ 2$ k.k. ${ }^{73}$ ), w których zagrożenie karą pozbawienia wolności wynosi od 3 lat do lat 15. Szczególnie restrykcyjne kary, za popełnienie przestępstw uregulowanych w art. 270a k.k. i 271a k.k., przewiduje art. 277a k.k. ${ }^{74}$ Jeśli kwota faktury (lub faktur) przekracza $10 \mathrm{mln}$ zł (dziesięciokrotność mienia „znacznej wartości” w rozumieniu art. $115 \$ 6$ k.k.), wtedy sprawca może oczekiwać kary od 5 do 15 lat lub kary nawet 25 lat pozbawienia wolności ${ }^{75}$.

Przed 1 marca 2017 r. fałszerstwo faktury regulował art. 270 k.k., dotyczący przerabiania lub podrabiania dokumentów celem ich użycia. Czyn był zagrożony karą ograniczenia wolności lub sankcją pozbawienia wolności od 3 miesięcy do 5 lat (art. 270 k.k. \$1). Ustawodawca nie przewidywał surowszej reakcji jak w przypadku typów zmodyfikowanych, tj. spraw „większej wagi” i regulacji z art. 277a k.k. ${ }^{76}$ Obok fałszerstwa dokumentów sprawca mógł odpowiadać za przestępstwo karno-skarbowe z tytułu art. $62 \$ 2$ k.k.s., tj. za nierzetelne wystawienie faktury lub posługiwanie się takim dokumentem. Sprawcy groziła wtedy wyłącznie kara grzywny w wysokości

71 Ustawa z dnia 6 czerwca 1997 r. - Kodeks karny..., art. 271a $\$ 1$.

72 T. Sroka, Komentarz do art. 270(a) Kodeksu karnego, [w:] Kodeks karny. Częśćszczególna. Tom I. Czesść II. Komentarz do art. 212277 d, red. W. Wróbel, A. Zoll, A. Oplustil-Barczak, [online] http://lex.adm. uj.edu.pl/lex/index.rpc?\&fromHistory=false\# content.rpc?nro=201337243\&wersja $=1 \&$ local Nro Part $=587746558,8$ I 2018.

73 M. Mozgawa, Komentarz aktualizowany do art.271(a) Kodeksukarnego, [w:] Kodekskarny. Komentarz aktualizowany, red. M. Mozgawa, M. Budyń-Kulik, M. Kozłowska-Kalisz, [online] http://lex. adm.uj.edu.pl/lex/index.rpc?\&fromHistory $=$ false\#content.rpc $?$ nro $=201337332 \& w e r s j a=-1 \&$ localNroPart $=587763147,31$ XII 2018.

$74 \quad$ Ustawa z dnia 6 czerwca 1997 r. - Kodeks karny..., art. 277a.

75 A. Lach, Komentarz do art. 277(a) Kodeksu karnego, [w:] Kodeks Karny. Komentarz, red. V. Wrzosek-Konarska, A. Lach, J. Lachowski, [online] http://lex.adm.uj.edu.pl/lex/index.rpc?\&fromHistory $=$ false\# content .rpcASKnro $=201337380 \&$ wersja $=1 \&$ localNroPart $=587773784 \&$ reqI $\mathrm{d}=1546541474589 \_1209043793 \&$ class $=$ CONTENT\&loc $=4 \&$ full $=1 \& \mathrm{hId}=8,3 \mathrm{I} 2019$.

76 W. Wróbel, T. Sroka, Komentarz do art. 270 Kodeksu karnego, [w:] Kodeks karny. Część szczególna. Tom I. Częś́ II. Komentarz do art. 212-277d, red. W. Wróbel, A. Zoll, A. Oplustil-Barczak, [online] http://lex.adm.uj.edu.pl/lex/index.rpc?\&fromHistory=false\#content.rpc--ASK--nro=201337243 \&wersja $=-1$ \&localNroPart $=587746557 \&$ reqId $=1546272744457 \_1710857678 \&$ class $=$ CONTENT \&loc $=4 \&$ full $=1 \& \mathrm{hId}=4,8$ I 2019. 
do 240 stawek dziennych ${ }^{77}$. W 2017 r. dokonano także nowelizacji kodeksu karno-skarbowego i obecnie obowiązują zaostrzone sankcje karne, dopuszczające m.in. orzekanie kary pozbawienia wolności ${ }^{78}$.

\subsection{Lud}

W uzasadnieniu projektu ustawodawcy pośrednio odwoływali się do mądrości ludu. Wskazywali, że za zmianą kodeksu karnego stoją przedsiębiorcy, którzy apelowali, aby państwo zapewniło odpowiednie warunki konkurencyjności i przestrzegania zasad wolnorynkowych (W1a). To właśnie osoby prowadzące działalność gospodarczą były dotychczas lekceważone. Ponadto, w sposób szczególny, pokreślono wysoką uczciwość przedsiębiorców, którzy najdotkliwiej odczuli skutki działalności przestępczej (W1f) ${ }^{79}$. Michał Wójcik, sekretarz stanu w Ministerstwie Sprawiedliwości, wspominał, że całe społeczeństwo domagało się zmian w tej materii, aby reakcja państwa była zdecydowana $(\mathrm{W} 1 \mathrm{ac})^{80}$. Wójcik thumaczył, że proponowane zmiany nie uderzają w osoby prowadzące działalność gospodarczą. Mówił: Mam wielu przyjaciót wśród przedsiębiorców. Podkreślał, że przedsiębiorcy nie tylko nie są oponentami nowelizacji, ale ją wręcz popierają. W ten sposób skrócił dystans pomiędzy politykami i sferą biznesu. Według niego obie te grupy mają ten sam cel - walkę z zorganizowaną międzynarodową przestępczością (W1d ${ }^{81}$. Współpraca ze środowiskiem biznesu była podkreślana również w procesie legislacyjnym. Z kolei Jerzy Jachnik z klubu Kukiz’15 w sposób dosadny nie zgodził się ze stanowiskiem Michała Wójcika. Stwierdził, że w wyniku zaproponowanej nowelizacji przedsiębiorcy będą traktowani jak zdechtepsy. Użyty przez niego związek frazeologiczny wskazywał, że osoby prowadzące działalność gospodarczą, w wyniku nowelizacji prawa karnego, znajdą się w szczególnie trudnym położeniu (W2b) ${ }^{82}$.

\subsection{Debata publiczna}

Politycy rzadko przeprowadzali zabieg administrowania strachem. Problem przestępczości podatkowej jest na tyle poważny, że ten element nie był silnie widoczny w konstruowaniu narracji politycznej. A jednak się pojawiał. Przykładowo Michał Wójcik,

77 I. Zgoliński, Komentarz do art. 62 Kodeksu karnego skarbowego, [w:] Kodeks karny skarbowy. Komentarz, red. I.Zgoliński, V. Konarska-Wrzosek, J.Skorupka, [online] http://lex.adm.uj.edu.pl/lex/ index.rpc\#content.rpc?nro=201337273\&wersja=-1\&localNroPart=587750073, 3 I 2019.

78 Ustawa z dnia 1 grudnia 2016 r. o zmianie ustawy o podatku od towarów i ustug oraz niektórych innych ustaw, Dz.U. 2016, poz. 2024.

79 Uzasadnienie Rzadowego projektu ustawy o zmianie ustawy... (s. 3).

$80 \quad$ Nagranie z 28 posiedzenia Sejmu Rzeczpospolitej Polskiej z dnia 19 października 2016 r., Pierwsze czytanie rzadowego projektu ustawy o zmianie ustawy - Kodeks karny oraz niektórych innych ustaw, druk nr 888, [online] http://www.sejm.gov.pl/Sejm8.nsf/transmisje_arch.xsp?rok=2016\&month=10\&type=posiedzenie\#DBD8516FBAFF197FC125805000453FFE, 13 I 2019, 13:15:25-13:15:40.

81 Tamże, 13:05:50-13:06:30.

82 Tamże, 13:45:20-13:45:25. 
podczas rozpatrywania przez Sejm stanowiska Senatu dotyczącego podsłuchów, z trybuny sejmowej mówił: [...] Prokuratura aresztowata kolejne osoby: Stowik, Parasol, Wańka - 14 osób. [...] Kilka dni temu z kolei kolejna zorganizowana grupa przestępcza i 700 mln wyjętych z budzetu. Chodzi o VAT (W2a) ${ }^{83}$.

W debacie publicznej pojawiały się ataki na oponentów politycznych. Kiedy jedna ze stron zwróciła uwagę na możliwość zainstalowania podsłuchu przez organy ściągania, który może ingerować w wolności jednostki, Michał Wójcik powiedział: Pani poset, wam Platformie nikt już nie dorówna. Prosze sobie sprawdzić statystykę, kto najchętniej podstuchiwat Polaków ${ }^{84}$ (W2c). Podczas trzeciego czytania sekretarz stanu skierował swoje słowa do posłów Platformy Obywatelskiej: [...] Państwo przez 8 lat nie reagowaliście na to [przestępstwa podatkowe - przyp. autora], a my przygotowujemy projekt, który wychodzi naprzeciw oczekiwaniom catego spoteczeństwa. Wójcik pokreślił po raz kolejny, że zmiany przygotowane w jego Ministerstwie realizują wolę wszystkich Polaków (W1ac). Następnie dodał: [...] Państwo przez 8 lat walczyliście $z$ biednymi ludźmi, a nie walczyliście $z$ mafiami. Taka jest brutalna prawda (W2c) ${ }^{85}$. Tym samym wskazywał, że politycy Platformy Obywatelskiej byli elitą, która lekceważyła zdanie najuboższej części społeczeństwa (W1e). Poseł Polskiego Stronnictwa Ludowego Krzysztof Paszyk, krytykując restrykcyjność projektu, stwierdził, że surowość kary jest bliska Ministrowi Ziobro. Osobista uwaga miała pokreślić, że ustawodawcy przyjęli punitywne sankcje tylko dlatego, iż Minister Sprawiedliwości rzekomo takie preferuje. Taka wypowiedź pośrednio dezawuuje również kompetencje członka Rady Ministrów, który skuteczność nowelizacji prawa karnego oparł wyłącznie na wprowadzeniu surowszych $\mathrm{kar}(\mathrm{W} 2 \mathrm{c})^{86}$.

Michał Wójcik kilkukrotnie mówił, że przestępcy podatkowi wysysają pieniądze z budżetu, na który składają się obywatele. Barwna metafora przedstawia oszustów fakturowych jako owady żerujące na zdrowym organizmie. Dzięki niej teza o zagrożeniu, jakie niosą ze sobą przestępcy podatkowi, jest bardziej zrozumiała dla przeciętnego odbiorcy $(\mathrm{W} 2 \mathrm{~b})^{87}$. Stosowana narracja stygmatyzuje również sprawców przestępstw (W6d). Wójcik pokreślił, że ostatni okres był dla grup przestępczych prawdziwym Eldorado ${ }^{88}$. Posłużył się związkiem frazeologicznym, który wskazywał, iż oszuści mogli działać, nie obawiając się reakcji ze strony organów ścigania (W2b). Używał rów-

83 Nagranie z 35 posiedzenia Sejmu Rzeczpospolitej Polskiej z dnia 10 lutego 2017 r., Rozpatrywanie na forum Sejmu stanowiska Senatu, w sprawie ustawy o zmianie ustawy - Kodeks karny oraz niektórych innych ustaw, druki nr 1260 i 1262, [online] http://www.sejm.gov.pl/Sejm8.nsf/transmisje_arch. $\mathrm{xsp}$ ? rok $=2017 \&$ month $=02 \&$ type $=$ posiedzenie $\#$ 565A2EF69DF5C1F3C12580BF00524932, 14 I 2019, 13:27:38-13:28:00.

$84 \quad$ Nagranie z 28 posiedzenia..., 14:11:30-14:11:45.

85 Nagranie z 34 posiedzenia Sejmu Rzeczpospolitej Polski z dnia 26 stycznia 2017 r., [online] http://www. sejm.gov.pl/Sejm8.nsf/transmisje_arch.xsp?rok=2017\&month=01\&type=posiedzenie\#724D0CA0A1A9B725C12580B3002AE24D, 14 I 2019, 19:42:58-19:45:55.

86 Tamże, 13:22:30-13:23:05.

87 Nagranie z 28 posiedzenia..., 13:06:20-13:06:26.

88 Tamże, 13:06:58-13:07:10. 
nież takich zwrotów jak: gangsterska dziatalność, gangsterzy, stupy, zorganizowane grupy przestępcze, kruczki prawne, charakterystyczne dla mowy potocznej, z użyciem różnych środków stylistycznych ${ }^{89}$.

Politycy nie unikali stosowania mowy potocznej również w pracach legislacyjnych, choć biorąc pod uwagę całokształt obrad, zdarzało się to im niezwykle rzadko. Przykładowo poseł Stanisław Pięta wypowiedział się w sposób następujący: Szanowni państwo, oszuści, którzy okradaja kraj, wystawiajac fatszywe faktury VAT, musza zostać zmiażdzeni. Kara zaproponowana przez Ministerstwo Sprawiedliwości jest jak najbardziej zasadna. Dziękuję. (W2b) ${ }^{90}$. Na szczególną uwagę zasługuje słowo „zmiażdżeni”. Sugeruje zdecydowaną reakcję państwa oraz pośrednio odczłowiecza sprawców (W2b).

Inicjatorzy zwrócili uwagę, że bardzo podobne rozwiązania prawne do tych proponowanych w Polsce sprawdzają się w innych państwach. W Zjednoczonym Królestwie za wyłudzenia podatku VAT na dużą skalę (tzw. spisek w celu oszukania publicznego budżetu) teoretycznie grozi kara nawet dożywotniego pozbawienia wolności. Najwyższa orzeczona kara w tym państwie wyniosła 17 lat bezwzględnej izolacji. Inicjatorzy przytoczyli także rozwiązania amerykańskie. $\mathrm{Na}$ ich podstawie, za popełnienie przestępstwa gospodarczego, sąd wydał wyrok w wysokości 150 lat pozbawienia wolności ${ }^{91}$. Z punktu widzenia różnic pomiędzy systemami prawa kontynentalnego i anglosaskiego bardzo ostrożnie powinno się prowadzić wszelkie zabiegi porównawcze. Ponadto w Stanach Zjednoczonych obowiązuje inny system sankcji niż w Polsce, gdzie przyjęto stosowanie tzw. kary łącznej ${ }^{92}$. Te dwa przykłady, mające uzasadniać potrzebę wprowadzenia restrykcyjnych sankcji, świadczą o pośredniej próbie manipulowania badaniami naukowymi. Zamiast prezentacji dorobku naukowego, który popierałby tezy wysuwane przez legislatorów, wskazano rozwiązania w państwach, które są kojarzone jako praworządne i samodzielne podmioty międzynarodowe. Pominięto natomiast różnicę pomiędzy systemem prawa polskiego (kontynentalnego) oraz systemami prawa amerykańskiego i brytyjskiego (anglosaskiego) (W2e).

Ten błąd częściowo miał zostać zrekompensowany przez nawiązania do zbliżonych regulacji obowiązujących w innych krajach należących do UE, które tworzą przepisy w oparciu o system prawa kontynentalnego. W żadnym analizowanym państwie ustawodawcy nie przewidzieli tak surowych kar pozbawienia wolności jak w Polsce. W Niemczech i Grecji, w przypadku poważniejszych przestępstw dotyczących fałszowania faktur, sprawcy grozi maksymalnie 10 lat pozbawienia wolności. W ten sposób inicjatorzy nowelizacji sami sobie zaprzeczyli. Przedstawili, że w innych państwach obowiązują łagodniejsze regulacje, niż te zaproponowane w polskim

Tamże, 13:08:35-13:10:40.

90 Posiedzenie Komisji Nadzwyczajnej do spraw zmian w kodyfikacjach, posiedzenie nr 28, 12 I 2017 r., biuletyn nr 1449/VIII, [online] http://orka.sejm.gov.pl/Zapisy8.nsf/wgskrnr/NKK-28., 12 I 2019.

91 Uzasadnienie Rządowego projektu ustawy o zmianie ustawy... (s. 8).

92 Ustawa $z$ dnia 6 czerwca 1997 r. - Kodeks karny..., art. 85. 
projekcie. Pomimo tego nie zrezygnowali z swojej inicjatywy lub nie obniżyli przewidzianych w niej kar $(\text { W3b })^{93}$.

Karol Stec, reprezentant Polskiej Organizacji Handlu i Dystrybucji ${ }^{94}$, na posiedzeniu podkomisji zwrócił uwagę, iż zagrożenie karą z art. 277a $\$ 1$ k.k. jest ewenementem na skalę światową. Pokreślił, że najsurowsze regulacje obowiązujące na terenie UE dotyczą zagrożenia karą do 10 lat pozbawienia wolności (W2d). Ponadto przedstawiciel przedsiębiorców nawiązał do najcięższych zbrodni, za popełnienie których grozi kara o podobnym poziomie punitywności, jak za czyny dotyczące fałszowania faktur. Uwaga ta została skomentowana przez prowadzącego obrady podkomisji Andrzeja Matusiewicza z Prawa i Sprawiedliwości słowami: To wiemy proszę Pana. Jako że prace podkomisji opierają się również na debacie publicznej ze specjalistami i przedstawicielami środowisk, których zmiany prawa dotyczą, uwaga przewodniczącego może zostać potraktowana jako forma marginalizowania wiedzy eksperckiej (W2d) lub jako próba dezawuacji zdania innej osoby $(\mathrm{W} 2 \mathrm{c})^{95}$.

\subsection{Proces legislacyjny}

Projekt przywidujący tak daleko idące zmiany powinien zostać odpowiednio skonsultowany z różnymi środowiskami biznesowymi i autorytetami prawniczymi. Dlatego na uwagę zasługuje ograniczony charakter konsultacji. Uwagi organizacji, instytucji i podmiotów pozarządowych zostały uwzględnione jedynie w niewielkim zakresie.

Projekt został zwolniony z obowiązku opracowywania założeń decyzją prezesa Rady Ministrów ${ }^{96}$. Ogranicza to przeprowadzenie wstępnych konsultacji społecznych najpierw nad założeniami, a dopiero później nad tekstem nowelizacji (W3a). Na wniosek Ministerstwa Sprawiedliwości ${ }^{97}$ Rada Ministrów opuściła cześć etapów procesu legislacyjnego. Uważano, że konieczność wprowadzenia szybkich zmian uzasadnia pominięcie oceny m.in. komisji prawniczej Rządowego Centrum Legislacji (RCL) (W3a) ${ }^{98}$.

Projektodawcy twierdzili, że projekt zmian został skonsultowany z grupq małych i średnich przedsiębiorców. Takie twierdzenie formułował przedstawiciel Ministerstwa

93 Ocena skutków regulacji Rządowego projektu ustawy o zmianie ustawy... (s. 5-6).

94 Polska Organizacja Handlu i Dystrybucji zrzesza przede wszystkim duże podmioty gospodarcze, które wykazują obroty w handlu detalicznym lub hurtowym powyżej $500 \mathrm{mln}$ zł rocznie. Należą do niej m.in.: Biedronka, Ikea, Lidl Polska, Żabka i Castorama. Zob. Polska Organizacja Handlu i Dystrybucji, [online] http://pohid.pl, 13 I 2019.

95 Nagranie $z$ posiedzenia podkomisji statej do spraw nowelizacji prawa karnego $z$ dnia 15 grudnia 2016 r., [online] http://www.sejm.gov.pl/Sejm8.nsf/transmisje_arch.xsp?unid=5522EA7D25CD4 BC3C125808200343E8B, 12 I 2019, 09:16:35-09:17:56.

96 Rządowe Centrum Legislacji, [online] https://legislacja.rcl.gov.pl/projekt/12288207/katalog/ 12370133\#12370133, 13 I 2019.

97 Pismo Ministerstwa Sprawiedliwości z dnia 8 września 2016 r., DL-III-400-7/16, [online] https://legislacja.rcl.gov.pl/projekt/12288207/katalog/12370166\#12370166, 12 I 2019.

98 Uchwata Nr 190 Rady Ministrów z dnia 29 października 2013 r. Regulamin pracy Rady Ministrów, M.P. 2013, poz. 979. 
Sprawiedliwości Tomasz Darkowski ${ }^{99}$. Michał Wójcik także podkreślał, że proponowane zmiany zostały odpowiednio omówione $z$ wieloma przedsiębiorcami. Nie sprecyzował, które podmioty miał na myśli ${ }^{100}$. Jednocześnie ogłosił, że Ministerstwo Sprawiedliwości jest otwarte na wszelkie sugestie, ale ze strony tych przedsiębiorców, którzy nie skupiają się wyłącznie na krytyce rządowej propozycji. Ograniczył w ten sposób liczbę podmiotów, z którymi dopuszcza rozmowy na temat proponowanych zmian (W3a) ${ }^{101}$. Ze strony internetowej RCL wynika, że jedyne uwagi ze strony przedsiębiorców, w ramach konsultacji społecznych, nadesłała Konfederacja Lewiatan (W2d) ${ }^{102}$. Organizacja zwróciła uwagę na brak precyzji w budowie niektórych przepisów. W wątpliwość podano również zbyt nisko uregulowane kwoty należności, które determinują poniesienie surowszej odpowiedzialności przez przedsiębiorców ${ }^{103}$. Podkreślono, że tak daleko idące zmiany ograniczające swobodę działalności gospodarczej wymagają licznych konsultacji społecznych ${ }^{104}$.

Ministerstwo Sprawiedliwości zapewniało, że proponowane zmiany były również konsultowane w gronie ekspertów prawnych, przy udziale przedstawicieli organów skarbowych, sędziów i prokuratorów ${ }^{105}$. Wprawdzie o planowanych zmianach poinformowano Naczelną Radę Adwokacką, Krajową Radę Radców Prawnych, Stowarzyszenie Sędziów Polskich „Iustitia” i Stowarzyszenie Sędziów „Themis”, ale, zgodnie z danymi RCL, nie otrzymano od nich żadnych uwag ${ }^{106}$. Na uwagę zasługuje również krótki, czternastodniowy termin na przesłanie swojej opinii na temat projektu, co mogło mieć wpływ na nieustosunkowanie się do proponowanych zmian przez wymienione podmioty (W3a) ${ }^{107}$.

Swoją opinię wyraziła natomiast Rada Legislacyjna (RL). Zwróciła uwagę na nadmierną kazuistykę nowelizacji. Dotyczyła ona wprowadzenia do kodeksu karnego

99 Posiedzenie Nadzwyczajnej Komisji...

100 Nagranie z 28 posiedzenia..., 13:05:50-13:06:36.

101 Nagranie z 28 posiedzenia...,13:18:40-13:18:55.

102 Konfederacja Lewiatan to organizacja dbająca o prawa pracodawców. Zrzesza ponad 4 tys. podmiotów. Zgodnie z przyjętymi założeniami stowarzyszenie dba o „konkurencyjne warunki prowadzenia biznesu, trwały wzrost gospodarczy, lepsze prawo, zdrową konkurencję, wzrost zatrudnienia i wzmocnienie kapitału społecznego". Zob. Konfederacja Lewiatan, [online] http://konfederacjalewiatan.pl/o_nas/o-lewiatanie, 13 I 2019.

103 W pierwotnym projekcie nowelizacji ustawy - Kodeks karny, przekazanym do konsultacji, w art. 277a $\S 1$ k.k. łączna wartość faktur musiała wynosić ponad $5 \mathrm{mln}$ zł, ażeby można było skazać sprawcę na karę pozbawienia wolności od lat 5 do lat 15 lub 25 lat. W wyniku prac legislacyjnych kwota należności wzrosła do $10 \mathrm{mln}$ zł. Była to w zasadzie jedyna uwaga przedsiębiorców, która pośrednio została uwzględniona przez legislatorów.

104 Uwagi Konferencji Lewiatan $z$ dnia 12 sierpnia $2016 r$. do projektu $z$ dnia 12 lipca $2016 r$ ustawy o zmianie ustawy - Kodeks karny oraz niektórych innych ustaw, [online] https://legislacja.rcl.gov.pl/ projekt/12288207/katalog/12370139\#12370139, 12 I 2019.

105 Posiedzenie Nadzwyczajnej Komisji...

106 Pismo Ministerstwa Sprawiedliwości z dnia 27 lipca 2016 r., DL III 400 7/16/19, [online] https:// legislacja.rcl.gov.pl/projekt/12288207/katalog/12370139\#12370139, 12 I 2019.

Tamże. 
nowych przestępstw. W ten sposób tworzy się niebezpieczny precedens, który spowoduje naruszenie sytemu prawa karanego. Rada uważała, że wprowadzenie nowego przestępstwa musi być poparte odpowiednim uzasadnieniem, którego autorzy projektu ustawy w sposób klarowny nie przedstawili (W3b) ${ }^{108}$. Większość uwag instytucji i środowisk prawniczych została uwzględniona przy okazji innych cech populizmu penalnego, w szczególności tych dotyczących zaostrzenia odpowiedzialności karnej. $\mathrm{Na}$ wysokie zagrożenie ustawowe sankcją karną zwracali uwagę przedsiębiorcy jeszcze w trakcie procedowania projektu (W5a). Karol Stec, przedstawiciel dużych sieci handlowych, uważał, że zagrożenie karą od 6 miesięcy do 8 lat pozbawienia wolności, przy nieostrych przesłankach ustawowych, może doprowadzić do znaczącego zwiększenia karalności. Argumentował, że osoby prowadzące działalność gospodarczą na dużą skalę otrzymują nawet kilkaset faktur dziennie (art. 270a $\$ 1$ k.k.). Takie podmioty nie są w stanie zweryfikować wszystkich dokumentów księgowych (W4) 4$)^{109}$. Podobna sytuacja ma miejsce, kiedy to uczciwy przedsiębiorca musi wystawić fakturę drugiej stronie transakcji (art. $271 \mathrm{a} \$ 1 \mathrm{k} . \mathrm{k}$. .). Wtedy również powinien zweryfikować partnera, ponieważ dokument przez niego przygotowany może posłużyć jako podstawa do wyłudzenia podatku VAT. Karol Stec zwrócił uwagę na problem tzw. karuzel podatkowych, w których przestępcy doskonale się maskują, udając autentyczne podmioty gospodarcze. Stec obawiał się, że niemożność weryfikacji takich podmiotów spowoduje, iż odpowiedzialnością karną będą obciążani uczciwi przedsiębiorcy, którym przypisze się znamię umyślności (W4) $)^{110}$.

Ponadto reprezentant dużych firm handlowych podkreślił, że przedmiotem przestępstwa jest wartość całej faktury (lub łączna wartość faktur), a nie realne uszczuplenie, które ponosi Skarb Państwa ${ }^{111}$. Podobną uwagę przedstawiło RCL. Eksperci uważali, że kara powinna być uzależniona od: faktycznego uszczuplenia należności publicznopraw$n e j$, a nie od wartości towaru lub usług, których na przykład sprzedaż jest dokumentowana fakturą. Specjaliści twierdzili, że propozycja legislatorów jest niezrozumiała i powoduje tylko zwiększenie represyjności nowelizacji (W3b, W5a $)^{112}$.

Obecni na obradach odnieśli się do argumentów przedstawiciela organizacji przedsiębiorców. Piotr Rogoziński z Ministerstwa Sprawiedliwości stwierdził, że przedsiębiorca, aby ponosił odpowiedzialność karną, musi działać umyślnie, a więc wymogiem jest świadomość, że faktura jest nieprawidłowa. Rogoziński podkreślit, że ustawa nie nakłada na przedsiębiorców obowiązku nadzwyczajnej weryfikacji kontrahentów. Wystarczy zastosować takie działania sprawdzające, jakie stosowali w swoich firmach

108 Opinia z 26 października 2016 r. o projekcie ustawy o zmianie ustawy - Kodeks karny oraz niektórych innych ustaw, RL-0303-29/16, [online] https://radalegislacyjna.gov.pl/dokumenty/opinia-z-26-pazdziernika-2016-r-o-projekcie-ustawy-o-zmianie-ustawy-kodeks-karny-oraz, 13 I 2019.

109 Nagranie z posiedzenia podkomisji..., 09:13:10-09:17:56.

110 Tamże, 09:39:46-09:43:27.

111 Tamże, 09:13:10-09:17:56.

112 Odpowiedź Rządowego Centrum Legislacji z dnia 12 sierpnia 2016 r., RCL.DPA.550.33/2016, [online] https://legislacja.rcl.gov.pl/projekt/12288207/katalog/12370133\#12370133, 13 I.2019, s. 2. 
od tej pory ${ }^{113}$. Podobną argumentację zawiera uzasadnienie projektu. Legislatorzy nie mają zamiaru penalizować czynów polegających na przypadkowym błędzie w fakturze. Innymi słowy, prokurator będzie musiał zgromadzić odpowiedni materiał dowodowy, z którego jednoznacznie będzie wynikać, iż sprawca działał umyślnie. Inaczej, $\mathrm{w}$ myśl zasady in dubio pro reo, czyn zostanie uznany za omyłkę ${ }^{114}$. Odmienne zdanie przedstawił Jacek Wilk, poseł należący ówcześnie do klubu parlamentarnego Kukiz’15. Wyraził podobne obawy jak reprezentant środowiska dużych podmiotów handlowych. Przedstawil się jako praktyk (adwokat), którego zdaniem sądy mają słabą wiedzę na temat procederu fałszowania faktur i przychylają się do wniosków prokuratury, która w materiale dowodowym wykazuje umyślność postępowania. Dlatego zdaniem posła zaostrzanie sankcji może być szczególnie niebezpieczne ${ }^{115}$. Pokreślił również, że badanie autentyczności każdej faktury, która wpłynęła od kontrahenta, jest niemożliwe. W przypadku większych podmiotów gospodarczych może się to równać z dodatkowymi kosztami, ponieważ firmy będą zmuszone zatrudnić odpowiednich specjalistów kontrolujących przeprowadzone transakcje. $\mathrm{Na}$ tę potencjalną konsekwencję ustawy inicjatorzy nie zwrócili uwagi (W4 $)^{116}$.

\subsection{Konsekwencje ustawy}

Projektodawcy nie przewidzieli, aby wprowadzone zmiany wymagały dodatkowego finansowania: Ewentualne wydatki dla budżetu państwa zwiazane z wprowadzeniem proponowanych rozwiązan będa finansowane w ramach dotychczasowych środków budżetowych w poszczególnych cześsiach budżetu państwa, bez konieczności ich zwiększania $w$ roku wejścia $w$ życie ustawy oraz w latach następnych. Jest to stanowisko dyskusyjne. Wprowadzenie surowszych sankcji, opartych na karze pozbawienia wolności, może spowodować konsekwencje finansowe. Pośrednio na tę kwestię zwrócili uwagę inicjatorzy projektu: Zgodnie z danymi Stużby Więziennej za rok 2015 [...] miesięczny koszt utrzymania osadzonego wynosit 3037 zt. Jednakże ustawodawcy planowali, że większe wydatki wymiaru sprawiedliwości i Służby Więziennej zostaną pokryte z uzyskanych dochodów, tj. z grzywien zasądzanych od sprawców oraz zwiększonych wpływów z wyegzekwowanego podatku VAT. Takie założenie jest niebezpieczne i może prowadzić do wywierania nacisku na organy ścigania, aby działały w sposób bardziej zdecydowany. Projektodawcy jednocześnie podkreślali, że nie są w stanie precyzyjnie określić skutków finansowych wprowadzonej regulacji, powołując się na novum proponowanych rozwiązań ${ }^{117}$.

Obok konsekwencji finansowych dla budżetu państwa należy wskazać te konsekwencje, które mogą objąć przedsiębiorców. Zwracano uwagę na dodatkowe kosz-

113 Nagranie z posiedzenia podkomisji..., 09.18:58-09:19:40.

114 Uzasadnienie Rzadowego projektu ustawy o zmianie ustawy... (s. 8-9).

115 Nagranie z posiedzenia podkomisji statej..., 09:19:50-09:20:41.

116 Nagranie z posiedzenia podkomisji statej..., 09:26:35-09:27:29.

117 Ocena skutków regulacji Rządowego projektu ustawy o zmianie ustawy... (s. 7). 
ty, które będą oni musieli ponieść w związku z wymogiem weryfikacji kontrahentów (W4). Ponadto istnieje potencjalne zagrożenie, iż w postępowaniu przygotowawczym prokuratorzy mogą wykazywać w stronie podmiotowej umyślność przedsiębiorcy mimo jej rzeczywistego braku (W4) $)^{118}$.

Na uwagę zasługuje stosunkowo krótkie vacatio legis, jak na tak daleko idące zmiany dla przedsiębiorców. Projekt zakładał, że ustawa wejdzie w życie po 14 dniach od momentu jej ogłoszenia ${ }^{119}$, czyli teoretycznie przyjęto minimalny okres ustawowy ${ }^{120}$. Prowadzący działalność gospodarczą mieli mało czasu, aby zapoznać się z wprowadzonymi zmianami i dostosować swoje firmy do nowych realiów prawnych (W4).

Posłowie Jerzy Jachnik (Kukiz'15), Janusz Sanocki (niezrzeszony) i Lidia Gądek (Platforma Obywatelska) zwracali uwagę, że proponowane zmiany w prawie karnym i ich punitywność zmusi przedsiębiorców do zmiany miejsca prowadzenia działalności gospodarczej na inny kraj w Europie (W4 $)^{121}$. Mirosław Pampuch, poseł klubu parlamentarnego Nowoczesna, wskazał, że po uchwaleniu procedowanej nowelizacji prawa karnego zagraniczni inwestorzy mogą mieć obawy związane z ulokowaniem swoich przedsiębiorstw w Polsce (W4) ${ }^{122}$. W tym miejscu należy jednak zauważyć, że argumenty, które padły w debacie parlamentarnej, mogą świadczyć o populizmie „w drugą stronę". Krytycy projektu nowelizacji kodeksu karnego próbują opinię publiczną skutkami ustawy, które w rzeczywistości mogą nie mieć miejsca.

Projektodawcy utrzymywali, że zmiana będzie skutkowała większą profesjonalizacją postępowania. Postępowanie karne ma być prowadzone nie przez urzędy skarbowe, ale przez policję i prokuratorów. Ci drudzy zostaliby odpowiednio wyselekcjonowani. Posiadaliby odpowiednie kwalifikacje, aby skutecznie sprawować nadzór nad śledztwem ${ }^{123}$. Pytanie, czy wcześniej organom skarbowym brakowało odpowiedniej wiedzy i umiejętności. Ponadto pomysłodawcy zmian uważali, że zmiana trybu z karno-skarbowego na stricte karny jest z korzyścią dla osoby podejrzanej. Według poprzednich regulacji organy skarbowe za czyny umyślne uznawały już niewłaściwą interpretację regulacji podatkowych, której dokonał domniemany sprawca (W5a) ${ }^{124}$. Należy pokreślić, że problem interpretacji podatkowych, które nierzadko rozmijają się z orzecznictwem sądowym, jest bardzo dotkliwą kwestią dla osób prowadzących działalność gospodarczą ${ }^{125}$. Argument ten nie przekonał przedsiębiorców, którzy podobne zagrożenie widzieli w działalności prokuratorów (problem przypisania umyślności).

118 Nagranie z posiedzenia podkomisji..., 09:39:46-09:43:27.

119 Ustawa $z$ dnia 10 lutego 2017 r., o zmianie ustaw..., art. 8.

120 Ustawa z dnia 20 lipca 2000 r. o ogtaszaniu aktów normatywnych i niektórych innych aktów prawnych, Dz.U. 2000, nr 62, poz. 718 , art. 4 ust. 1.

121 Nagranie z 34 posiedzenia Sejmu Rzeczpospolitej Polski z dnia 26 stycznia 2017 r., 13:11:06-13:37:23.

122 Tamże, 19:40:12-19:41:30.

123 Uzasadnienie Rządowego projektu ustawy o zmianie ustawy... (s. 10).

124 Tamże.

125 W. Morawski, Interpretacje prawa podatkowego i celnego - stabilność i zmiana, Warszawa 2012, s. 31. 
Twierdzili, że zmiana organów odpowiedzialnych za zgromadzenie materiału dowodowego nie gwarantuje, że ich prawa będą przestrzegane (W4) ${ }^{126}$.

\subsection{Prawo karne}

Legislatorzy, w sposób szczególny, pokreślili potrzebę wprowadzenia surowych kar, które gwarantowałyby prewencję ogólną. Opiera się ona na odstraszaniu potencjalnych przestępców od popełnienia czynu zabronionego. Ponadto sprawca, dokonując chłodnej kalkulacji, zastanowi się, czy potencjalne korzyści uzyskane z przestępstwa są znacząco wyższe od ryzyka, jakie się z nim wiąże. Michał Wójcik podkreślił, że: Chodzi bowiem o to, by tego typu zachowania zmierzajace do nielegalnego uzyskania środków finansowych kosztem budżetu pansstwa staty sięnieoptacalne, a odpowiednio surowa sankcja karna miata walor odstraszajacy potencjalnych sprawców (W5a ${ }^{127}$.

Ustawodawcy wskazywali, że dotychczasowe kary są niewystarczające i nie zapewniają odpowiedniej ochrony interesu ekonomicznego Polski. Uważali, że liczba najgroźniejszych sprawców, skazanych na karę bezwzględnego pozbawienia wolności, jest niewystarczająca, biorąc pod uwagę zagrożenie, jakie oni stanowią: [...] wystarczy wskazać, że wokresie 2014-2016, w sprawach, których przedmiotem byty wytudzenia nienależnego zwrotu podatku VAT co najmniej dużej wartości, zapadty wyroki wobec 253 osób, z czego jedynie 31 osób skazanych zostato na kary pozbawienia wolności bez warunkowego zawieszenia ich wykonania $(\mathrm{W} 5 \mathrm{a})^{128}$. Ponadto, orzekając na podstawie art. 62 k.k.s., sądy wymierzały głównie kary grzywny. W latach 2014-2016 tę sankcję zastosowano samoistnie 733 razy. Z kolei karę bezwzględnego pozbawienia wolności wymierzono 17 razy (W5a) ${ }^{129}$.

Projektodawcy porównali przestępstwa fakturowe, powodujące duże straty dla budżetu państwa, do najcięższych zbrodni. Wymieniano: zabójstwo, przestępstwa przeciwko pokojowi lub ludzkości oraz przestępstwa wojenne. Inicjatorzy nowelizacji domagali się tym samym wprowadzenia tak samo surowych sankcji karnych zarówno pod względem ilościowym, jak i rodzajowym (W5a) ${ }^{130}$.

Zagrożenie karą pozbawienia wolności od lat 5 do lat 15 lub karą 25 lat pozbawienia wolności jest bez wątpienia sankcją niezwykle surową (art. 277a \$1 k.k.). Zastrzeżenia w tej kwestii miały RCL ${ }^{131}$ i Krajowa Rada Sądownictwa (W3b) ${ }^{132}$. Sąd Najwyższy (SN) uważał, że planowane kary są nieproporcjonalne do wagi czynów.

126 Nagranie z posiedzenia podkomisji..., 09:39:46-09:43:27.

Uzasadnienie Rządowego projektu ustawy o zmianie ustawy... (s. 1-2).

128

129 Ocena skutków regulacji Rządowego projektu ustawy o zmianie ustawy... (s. 3).

130 Uzasadnienie Rządowego projektu ustawy o zmianie ustawy... (s. 5).

131 Odpowiedź Rządowego Centrum..., s. 3.

132 Opinia Krajowej Rady Sąownictwa z dnia 16 września 2016 r. w przedmiocie projektu ustawy o zmianie ustawy - Kodeks karny oraz niektórych innych ustaw, WO 020-125/16, UD107, [online] www. $\mathrm{krs.pl} / \mathrm{pl} /$ dzialalnosc/opinie-i-stanowiska/f,182,opinie-i-stanowiska-2016-r/612,12-15-wrzesnia2016-roku/4374,opinia-krajowej-rady-sadownictwa-z-dnia-16-wrzesnia-2016-r-nr-wo-020-12516-u d107, 13 I 2019, s. 1-2. 
Nie zgodził się na rozbicie spójności kodeksu karnego. SN podkreślił, że ustanowienie podobnego lub nawet wyższego zagrożenia ustawowego za fałsz intelektualny faktury jak za handel ludźmi (art. 189 \$1 k.k.) lub gwałt w typie kwalifikowanym (art. 197 $\$ 2-4$ k.k.) jest wysoce nieracjonalnym działaniem ze strony ustawodawcy. Organ wprost zwrócił uwagę, iż taki proceder ma znamiona populizmu penalnego (W3b, W5a $)^{133}$. Ponadto SN zwrócił uwagę, że wzrost punitywności kar limituje swobodę sędziów w precyzowaniu sankcji. Ustawodawca ogranicza w ten sposób dostosowanie kary do konkretnego przestępstwa popełnionego przez indywidualnego sprawcę (W5a) ${ }^{134}$. Podobne zdanie miała RL. Uznała ona, że są dobra prawne ważniejsze niż interes finansowy państwa, a mimo to za ich naruszenie grożą niższe kary niż za fałszowanie faktur (W5a).

Co więcej, eksperci z RL i SN stwierdzili, iż prawo karne nie powinno być wiodącą gałęzią prawa, regulującą przestępstwa przeciwko wiarygodności faktur. Środki, które wprowadza prawo karne, są zbyt dotkliwe dla przedsiębiorców. Pokreślono, że te same cele mogą zostać osiągnięte za pomocą innych mechanizmów, które w mniejszym stopniu będą ingerować w prawa i wolności jednostek, i tym samym będą zgodne z zasadą demokratycznego państwa prawa (W5b) ${ }^{135}$. Warto nadmienić, że ustawodawcy wdrożyli również inne środki w oparciu o przepisy prawa podatkowego, m.in. jednolity plik kontrolny lub transakcje split payment ${ }^{136}$. Wprowadzone mechanizmy bez wątpienia obniżają populistyczny charakter przestępstw fakturowych, ponieważ w wyższym stopniu oddziałują na poziomie predeliktualnym. Przez to należy ocenić je w sposób pozytywny.

W kontekście surowych sankcji należy zwrócić uwagę na dwie kwestie bezpośrednio związane z polityką karną i penitencjarną. Wskutek nowelizacji prawa karnego w 2015 r. ${ }^{137}$ ustawodawca pokreślił prymat kar wolnościowych. Zaostrzając zagrożenia ustawowe karą pozbawienia wolności, projektodawcy działają w opozycji do wcześniejszych założeń. Zamiast czynić prawo bardziej racjonalnym, aktualna tendencja zmierza raczej ku jego surowości ${ }^{138}$. Natomiast problem polityki penitencjarnej dotyczy wysokiego wskaźnika prizonizacji1 ${ }^{139}$. W 2018 r. w Polsce wyniósł 192. Jest on jednym

133 Uwagi Sądu Najwyższego z dnia 27 lipca 2016 r. do projektu ustawy o zmianie ustawy - Kodeks karny i niektórych innych ustaw, BSA II 021349/16, [online] https://legislacja.rcl.gov.pl/projekt/12288207/ katalog/12370145\#12370145, 13 I 2019, s. 4-5.

134 Uwagi Sądu Najwyższego..., s. 4.

135 Opinia Rady Legislacyjnej...

136 Najwyższa Izba Kontroli, Przeciwdziatanie wytudzeniom podatku VAT, Informacja o wynikach kontroli, nr ewid. 23/2018/P/17/013/KBF, 19 IV 2018 r., [online:] https://www.nik.gov.pl/kontrole/P/17/013/, 10 V 2019, s. 9.

137 Ustawa z dnia 20 lutego 2015 r. o zmianie ustawy - Kodeks karny oraz niektórych innych ustaw, Dz.U. 2015, poz. 396.

138 R. Kokot, Podstawy stosowania kar wolnościowych w kodeksie karnym z 1997 r. po nowelizacji z 20 lutego 2015 r., „Nowa Kodyfikacja Prawa Karnego” 2015, t. 37, s. 67-70.

139 Jest to stosunek liczby osób powyżej 18 roku życia pozbawionych wolności, przypadających na 100 tys. obywateli danego państwa. 
z najwyższych w Unii Europejskiej (wyższy posiadają jedynie Litwa, Łotwa, Estonia i Czechy $)^{140}$. Jeśli sądy będą orzekać wysokie kary izolacyjne, to liczba osób osadzonych oraz w konsekwencji współczynnik prizonizacji będą rosły.

Przedstawiciel Prokuratury Krajowej, odpierając ataki, przedstawił swoją opinię. Wskazał, że takie samo zagrożenie jak w przypadku fałszu intelektualnego faktury jest przewidziane w art. $310 \$ 1$ k.k. ${ }^{141}$, który penalizuje podrabianie pieniędzy. Innymi słowy, Ministerstwo Sprawiedliwości uważało, że skoro podrabianie środków płatniczych stanowi zagrożenie dla bezpieczeństwa ekonomicznego Polski, podobnie jak przestępstwa fakturowe, to zastosowanie tak samo dolegliwej sankcji w art. $277 \mathrm{a} \$ 1$ k.k. jest jak najbardziej uzasadnione (W5a). Zauważono jednak, że przestępstwo z art. $310 \$ 1$ k.k. jest również uregulowane zbyt restrykcyjnie. Wpływ na taki stan prawny mają wątki o charakterze historycznym, ponieważ w przeszłości czyn ten był uznawany za jedno z najbardziej poważnych przestępstw. Obecnie inne formy zorganizowanej działalności przestępczej są większym zagrożeniem dla bezpieczeństwa ekonomicznego państwa niż podrabianie pieniędzy ${ }^{142}$.

W kontekście dyskusji o art. $310 \$ 1$ k.k. głos zabrał stały doradca komisji Jarosław Świeczkowski. Wskazal, że: Mimo zagrożenia sankcja 25 lat pozbawienia wolności, $w 2011$ r. za przestępstwo $z$ art. 310 \& 1 jedynie $w$ niespetna 26\% przypadków doszto do orzeczenia bezwzględnej kary pozbawienia wolności. W3/4 przypadków sady orzekaty kare $z$ warunkowym zawieszeniem wykonania. Orzeczenie kary w przedziale od 5 do 8 lat miato miejsce tylko w przypadku 5\% ogótu skazań, a więc bardzo rzadko. Nie odnotowano żadnego skazania powyżej 8 lat. Oczywiście, nie odnotowano także żadnego skazania na karę 25 lat pozbawienia wolności. Świadczy to o tym, że sady doskonale sobie poradzity z tym problemem $^{143}$. Podobnych argumentów użył przewodniczący nadzwyczajnej komisji sejmowej Arkadiusz Mularczyk: Pozwolę sobie opowiedziećpaństwu o jednej z pierwszych spraw, które prowadzitem jako adwokat. (...) Chodzito o kilku chtopców, którzy fatszowali banknoty na kserokopiarce. (...) Sad bardzo się musiat nagimnastykować, ale ostatecznie ich nie skazat, tzn. warunkowo zawiesit wykonanie kary. Myśle, że nikt z nas nie wierzy, że w tego rodzaju przypadkach sady będa orzekaty kary 25 lat pozbawienia wolności. Raczej skorzystaja one z przepisów umożliwiających wymierzenie tagodniejszej kary ${ }^{144}$. W kontekście tych dwóch wypowiedzi pojawia się zasadniczy problem. Po co ustanawiać wysokie zagrożenie karą pozbawienia wolności, skoro nie ma się zamiaru korzystać z uregulowań?

Warto zwrócić uwagę na jeszcze coś innego. Czy w ogóle znajdą się czyny na tyle społecznie szkodliwe i na tyle zawinione, aby wymierzyć karę 25 lat pozbawienia wolności ? ${ }^{145}$ Jeśli sąd nie będzie korzystał z górnego ustawowego zagrożenia karą, to w ta-

140 Prison Population Rate in Poland in 2018, [online] http://www.prisonstudies.org/country/poland, 19 I 2019.

141 Ustawa z dnia 6 czerwca 1997 r. - Kodeks karny..., art. $310 \$ 1$.

142 Posiedzenie Nadzwyczajnej Komisji...

143 Tamże.

144 Tamże.

145 Ustawa z dnia 6 czerwca 1997 r. - Kodeks karny..., art. $53 \S 1$. 
kiej sytuacji wprowadzone regulację będą niepotrzebne. W konsekwencji staną się martwym prawem. Ponadto walor odstraszający kary może ulec osłabieniu, jeśli przestępcy stwierdzą, że sąd nie orzeka najsurowszych sankcji.

Zaostrzenie prawa karnego może występować pod różnymi postaciami, które niekoniecznie wprost oznaczają wprowadzenie wyższego zagrożenia ustawowego. Przykładem takich działań jest możliwość prowadzenia czynności operacyjno-rozpoznawczych przez uprawnione organy, m.in. Policję ${ }^{146}$, Centralne Biuro Antykorupcyjne $^{147}$ czy Straż Graniczną ${ }^{148}$. Służby, w celu przeciwdziałania, wykrycia sprawcy i uzyskania dowodów na fałszerstwo faktur, będą mogły po spełnieniu przesłanek ustawowych na przykład założyć podsłuch telefoniczny ${ }^{149}$. Czynności operacyjno-rozpoznawcze budzą liczne wątpliwości konstytucjonalistów jako środki nadmiernie ingerujące w wolność jednostki (prawo do życia prywatnego, tajemnicę korespondencji itd.). Powinny być stosowane tylko w takim zakresie, w jakim jest to konieczne, aby osiągnąć zakładany cel $^{150}$. Organy państwa powinny mieć na uwadze konstytucyjną zasadę proporcjonalności ${ }^{151}$. Pojawia się więc pewna obawa, że środki o nadzwyczajnym charakterze będą nadużywane (W5a).

Warto pokreślić, że projekt pierwotnie zakładał niższe kwoty faktur, od których zależało popełnienie przestępstwa w postaci kwalifikowanej. W projekcie, który wpłynął do sejmu w art. 270 a $\$ 2$ k.k. i art. 271a $\$ 2$ k.k., wystarczyła łączna wartość faktur na poziomie $1 \mathrm{mln}$ zł. Z kolei, aby sprawca odpowiadał z art. 277a $\$ 1$ k.k., łączna wartość faktur musiała wynosić ponad $5 \mathrm{mln} \mathrm{z}^{152}$. Zmiany zostały zaproponowane na Komisji Sejmowej i zakładały następujące wartości: w art. $270 \mathrm{a} \$ 2$ k.k. i art. $271 \mathrm{a} \$ 2$ k.k. - ponad $5 \mathrm{mln}$ zł oraz w art. $277 \mathrm{a} \S 1$ k.k. - ponad $10 \mathrm{mln} \mathrm{zf}^{153}$. Sugestie te pozwolity na zmniejszenie punitywności ustawy. Innymi słowy, osoba dokonująca fałszerstwa faktury będzie odpowiadać za przestępstwo kwalifikowane, które cechuje się wyższą nagannością czynu i tym samym większym zagrożeniem ustawowym, jeśli jej zachowanie będzie odpowiednio bardziej dotkliwe dla budżetu państwa (W5a).

146 Ustawa z dnia 6 kwietnia 1990 r. o Policji, Dz.U. 1990, nr 30, poz. 179, art. 19 ust. 1 pkt 2.

147 Ustawa z dnia 9 czerwca 2006 r. o Centralnym Biurze Antykorupcyjnym, Dz.U. 2006, nr 104, poz. 708, art. 17 ust. 1 pkt 1.

148 Ustawa z dnia 12 października 1990 r. o Straży Granicznej, Dz.U. 1990, nr 78, poz. 462, art. 9f ust. 1 pkt 2.

149 Uzasadnienie Rządowego projektu ustawy o zmianie ustawy... (s. 10-11).

150 T. Grzegorczyk, Pozaprocesowa kontrola rozmów jako legalne wkraczanie w sferę konstytucyjnie chronionej wolności i tajemnicy komunikowania sie, po zmianie przepisów w tej materii w $2011 \mathrm{r}$., [w:] Państwo prawa i prawo karne. Ksiega jubileuszowa Profesora Andrzeja Zolla, tom II, red. P. Kardas, T. Sroka, W. Wróbel, Warszawa 2012, [online] http://lex.adm.uj.edu.pl/lex/index.rpc?\&fromHistory=false\#content.rpc?nro=151225451\&wersja=-1\&, 10 I 2019.

151 Konstytucja Rzeczypospolitej Polskiej $z$ dnia 2 kwietnia 1997 r. uchwalona przez Zgromadzenie Narodowe $w$ dniu 2 kwietnia 1997 r., przyjęta przez Naród w referendum konstytucyjnym w dniu 25 maja 1997 r., podpisana przez Prezydenta Rzeczypospolitej Polskiej w dniu 16 lipca 1997 r., Dz.U. 1997, nr 78 , poz. 483 , art. 31 ust. 3 .

152 Ustawa $z$ dnia 10 lutego 2017 r., o zmianie ustaw..., art. 270a $\$ 2$, art. 271a $\$ 2$, art. 277a $\$ 1$.

153 Posiedzenie Nadzwyczajnej Komisji... 
Co więcej, legislatorzy uważali, że prawo karne jest najwłaściwszym środkiem do zwalczania przestępstw przeciwko wiarygodności faktur. Podkreślali, że inne gałęzie prawa nie są tak efektywne jak reakcja o charakterze represyjnym: Środki o charakterze administracyjnoprawnym nie mogą być uznane w tym zakresie za skuteczne, gdyż ich dolegliwość nie przystaje w żadnym stopniu do rozmiarów szkód ogólnospołecznych spowodowanych tymi zachowaniami (W5b) ${ }^{154}$. Tym samym w uzasadnieniu projektu nie uwzględniono uwag RL i SN (W3b).

\subsection{Sprawca i ofiara}

Ustawodawcy zwracali uwagę na skalę zjawiska: Podstawowym zagadnieniem jest unaocznienie, że straty Skarbu Państwa spowodowane wytudzeniami zwiazanymi z podatkiem VAT sa bardzo wysokie i znaczaco odczuwalne w systemie budżetowym państwa - należności, które nie wptywaja do budżetu państwa, można liczyć w dziesiątkach miliardów $z t o t y c h^{155}$.W tej kwestii trudno upierać się przy micie wysokiej przestępczości, który jest charakterystyczny dla populizmu penalnego. Zagrożenia mają charakter jak najbardziej realny. Ustawodawcy wskazali, że w 2013 r. organy skarbowe wykryły fikcyjne faktury wystawione na łączną kwotę $19,7 \mathrm{mld}$ zł. W 2015 r. było to już 81,9 mld zt ${ }^{156}$.Legislatorzy powołali się na dane zgromadzone przez Najwyższą Izbę Kontroli (NIK). Ponadto NIK podkreślit, iż: dotychczasowe regulacje prawne oraz dziatania okazaty się niewystarczajace i nie pozwalaja na skuteczne zabezpieczenie interesów Skarbu Państwa. Urzędnicy wskazali, że ustawodawcy powinni wdrożyć nowe inicjatywy, ponieważ instrumenty prawne, takie jak na przykład odwrócony mechanizm podatkowy, są niewystarczające. Jednakże wśród proponowanych rozwiązań NIK nie wskazał wprost, że konieczne jest oddziaływanie represją karną. Skupiono się na działaniach predeliktualnych, zmianach w rozliczeniach z organami skarbowymi oraz zwiększonej współpracy międzyinstytucjonalnej ${ }^{157}$.

Problem z tzw. luką podatkową ${ }^{158}$ zauważa także UE. W 2012 r. lukę w Polsce szacowano na 116 mld zł, a w 2016 r. już na 133 mld zł. Z drugiej strony udział luki w przychodach teoretycznych (VTTL) maleje. W 2012 r. taki stosunek wyniósł 27\%, a w 2016 r. - 21\%. Powodem omawianej sytuacji są stale rosnące, zarówno szacunkowe, teoretyczne wpływy z podatku od towarów i usług, jak i wpływy z VAT-u w rzeczywistości egzekwowanego ${ }^{159}$. Mimo że procentowy udział luki we wpływach teo-

154 Uzasadnienie Rzadowego projektu ustawy o zmianie ustawy... (s. 5).

155 Tamże.

156 Ocena skutków regulacji Rządowego projektu ustawy o zmianie ustawy... (s. 1).

157 Najwyższa Izba Kontroli, Przeciwdziatanie wprowadzaniu do obrotu gospodarczego faktur dokumentujących czynności fikcyjne, Informacja o wynikach kontroli, nr ewid. P/15/011/KBF, 23 III 2016 r., [online:] https://www.nik.gov.pl/kontrole/P/15/011/KBF/, 18 I 2019, s. 10-14.

158 Luka VAT (VAT Gap) to różnica między szacowanymi, teoretycznymi przychodami z podatku od towarów i usług (VTTL) i rzeczywistymi wpływami z VAT do budżetu. Można ją wyrazić procentowo jako udział luki podatku VAT w przychodach teoretycznych (VTTL).

159 Study and Reports on the VAT Gap in the EU-28 Member States: 2018 Final Report, [online] https:// ec.europa.eu/taxation_customs/business/tax-cooperation-control/vat-gap_en, 13 I 2019, s. 43. 
retycznych maleje, to i tak jest on jednym z najwyższych w UE (większy ma jedynie: Grecja, Włochy, Litwa, Rumunia i Słowacja). Ponadto w 2016 r. uśredniony udział luki VAT w VTTL dla całej UE wyniósł $12 \%{ }^{160}$. Inicjatorzy zmian w prawie karnym podkreślali, że ofiarą przestępców podatkowych jest całe społeczeństwo. Straty, które ponosi budżet, dotykają każdego obywatela z osobna oraz wspólnotę jako całość. Tym samym mamy do czynienia z podwójną wiktymizacją (W6b) ${ }^{161}$. Sekretarz stanu Michał Wójcik pokreślił, że w wyniku oszustw fakturowych: my wszyscy na tym tracimy. Poglądy polityczne, wyznanie, zawód nie mają większego znaczenia. Natomiast szczególną podatnością wiktymizacyjną charakteryzowali się według niego przedsiębiorcy $(\mathrm{W} 6 \mathrm{~b})^{162}$.

Ustawodawcy wskazywali, że pieniądze skradzione przez przestępców ograniczają prowadzenie skutecznej polityki opartej na redystrybucji dóbr. Pokreślono w ten sposób potrzeby społeczeństwa i nierówności ekonomiczne, które powinny znaleźć się w centrum zainteresowania państwa(W6c) ${ }^{163}$. Michał Wójcik w pierwszym czytaniu pokreślił, że pieniądze, które państwo traci w wyniku oszustw, mogłoby przeznaczyć na stużbę zdrowia, edukacje, ulice, szkoty wyższe. Ponadto zwrócił się bezpośrednio do ludzi młodych, którzy siedzieli na galerii nad salą posiedzeń. Wskazał, że oni również są poszkodowani przez przestępców (W2b). Z kontekstu wypowiedzi wynikało, że proponowane zmiany odwrócą polaryzację. Przejęte środki, pochodzące z działalności przestępczej, zostaną przeznaczone na wymienione wyżej dziedziny życia $(\text { W } 6 \mathrm{c})^{164}$.

\section{PODSUMOWANIE}

Nie sposób udzielić jednoznacznej odpowiedzi na pytanie o to, czy populizm penalny jest zjawiskiem o wyłącznie negatywnym charakterze. Wiele postulatów głoszonych przez populistów ma charakter proobywatelski, w szczególności te dotyczące demokracji bezpośredniej. Dyskusyjne jest traktowanie populizmu wyłącznie jako patologii systemowej ${ }^{165}$. Margaret Canovan wspominała, że populizm jest paradoksem współczesnych demokracji. Część instytucji prawnych jest dla przeciętnego obywatela niezrozumiała. Przez to demokracja, wbrew swoim założeniom, zamyka się na czynnik ludzki. Populiści proponujący uproszczoną wizję rzeczywistości są atrakcyjni dla obywateli ${ }^{166}$.

160 Tamże, s. 80.

161 Uzasadnienie Rządowego projektu ustawy o zmianie ustawy... (s. 6).

162 Nagranie z 28 posiedzenia..., 13:05:26-13:06:44.

163 Uzasadnienie Rządowego projektu ustawy o zmianie ustawy... (s. 6).

164 Nagranie z 28posiedzenia..., 13:08:58-13:09:10.

165 Y. Meny, Y. Surel, The Constitutive Ambiguity of Populism, [w:] Democracies and the Populist Challenge, red. ciż, London 2002, s. 3-7.

166 M. Canovan, Taking Politics to the People: Populism as the Ideology of Democracy, [w:] Democracies and the Populist Challenge, red. Y. Meny, Y. Surel, London 2002, s. 25-26. 
Canovan porównywała populizm do cienia rzucanego przez demokrację. Świadczy to o koegzystencji demokracji i populizmu ${ }^{167}$.

Populizm nie jest jednorodny. Należy rozróżniać dwa rodzaje zachowań polityków. Pierwsze, nakierowane wyłącznie na popularność polityczną („twardy populizm”) i drugie odnoszące się do inicjatyw pozytywnych, zmierzających do efektywnego karania. Dzięki „miękkiemu populizmowi” można wypracować skuteczną politykę karną. W tym przypadku populizm jest „półśrodkiem” albo przystankiem na właściwej drodze do osiągnięcia pożądanego celu ${ }^{168}$.

Przedstawionego przykładu nowelizacji prawa karnego nie należy łączyć bezpośrednio z „twardym populizmem” penalnym. Wiele elementów typowych dla populizmu w analizowanym przypadku nie występuje lub ich nasilenie nie jest na tyle wyraźne, aby uznać demagogicznych charakter poszczególnych struktur. Przede wszystkim w sposób bardziej merytoryczny prowadzono debatę publiczną. Podczas przebiegu procesu legislacyjnego uwagi natury czysto populistycznej nie przekraczały akceptowalnego poziomu, normalnego w demokratycznym ustroju. Wpływ na taką sytuację ma bardziej skomplikowany charakter zmian, który wymaga od uczestników życia publicznego pewnego poziomu wiedzy, wykraczającego poza ogólny zasób informacji o świecie.

Należy zauważyć, że w analizie pominięto narracje stricte medialną na przykład uczestnictwo w programach publicystycznych, aktywność na portalach społecznościowych, wypowiedzi na konferencjach prasowych. Można przypuścić, że narracja prowadzona w środkach masowego przekazu będzie zawierać więcej elementów populistycznych. Natomiast porównując sposób prowadzenia debaty parlamentarnej w analizowanym przypadku do nowelizacji o dużym ładunku społecznym, na przykład do tzw. ustawy o bestiach ${ }^{169}$, to różnice są ewidentne. Zmiany ustaw, które budziły szczególne zainteresowanie społeczeństwa, charakteryzowały się większym udziałem populistycznego dyskursu na poziomie prac parlamentarnych.

Nie zaobserwowano również tzw. mitu wysokiej przestępczości, a administrowanie strachem w narracji polityków pełniło marginalną rolę. Przyczyną takiego stanu rzeczy jest realnie istniejące zagrożenie. Przestępstwa podatkowe, w szczególności dotyczące VAT, są poważnym wyzwaniem dla państwa polskiego, co podkreślają zarówno władze krajowe, jak i Unia Europejska. Trudno było również wskazać w dyskursie politycznym antyelitaryzm. Pewne elementy, wskazujące na budowanie antynomii społecznej, można wywnioskować z ataków politycznych ze strony osób popierających projekt ustawy na partię współrządzącą w Sejmie VI i VII kadencji - Platformę Obywatelską. Jednakże

167 M. Canovan, Trust..., s. 16.

168 J. V. Roberts, L. J. Stalans, D. Indermaur, M. Hough, Penal Populism and Public Opinion. Lessons from Five Countries, Oxford 2003, s. 5.

169 Zob. Posiedzenie Komisji Nadzwyczajnej do rozpatrzenia poselskiego projektu ustawy o zmianie ustawy - Kodeks karny oraz Kodeks karny wykonawczy i rzadowego projektu ustawy o postępowaniu wobec osób z zaburzeniami psychicznymi stwarzajacych zagrożenie życia, zdrowia lub wolności seksualnej innych osób, posiedzenie nr 2, 11 IX 2013 r., biuletyn nr 2315/VII, http://orka.sejm.gov.pl/Zapisy7.nsf/ wgskrnr/NZP-2, 15 I 2019. 
nie są to wątki na tyle wyraźne, aby jednoznacznie przesądzały o antyelitarnej narracji. Wskazują raczej na próby dezawuowania oponentów politycznych.

Analizując materiał badawczy pod kątem obecności dyskursu populistycznego, bardzo trudno było oddzielić poszczególne czynniki od siebie. W jednej wypowiedzi lub w danym fragmencie dokumentu występowało wiele wątków wskazujących na demagogiczny charakter narracji lub treści. Bardzo charakterystyczne jest więc przenikanie się poszczególnych kategorii, które składają się na ogólny model narracji populistycznej. Ponadto problematyczny był również tzw. populizm w drugą stronę. Argumenty używane przez oponentów nowelizacji, z pozoru krytykujące populistyczne zapędy ustawodawców, również zawierały w sobie elementy demagogiczne.

Proponowanym zmianom bliżej jest do „populizmu miękkiego”. Dlatego też nie wszystkie założenia ustawodawców zasługują na wyraźną krytykę. Należy podzielić opinie inicjatorów zmian w prawie karnym na temat problemów ze szczelnością polskiego sytemu podatkowego. Uważali oni, że państwo nie radzi sobie z wyłudzeniami podatku od towaru i usług. Wskazywali, że zarówno porządek prawny, jak i praktyka funkcjonowania organów publicznych są nieadekwatne do zagrożenia, jakim są zorganizowane struktury przestępcze powodujące miliardowe straty dla budżetu ${ }^{170}$. Potrzebę zmian poparł również prezydent: Uchwalenie niniejszej ustawy uwidacznia nowe, surowsze podejście do kwestii karania sprawców przestępstw wprowadzanych ustawa, co wynika z przekonania ustawodawcy, iż dolegliwość dotychczas stosowanych kar nie przystawata $w \dot{z}$ adnym stopniu do rozmiarów spowodowanych szkód ${ }^{171}$. Jednak należy podać w wątpliwość sposób, w jaki ustawodawca zdecydował się rozwiązać problem luki podatkowej. Najpoważniejsze zarzuty ekspertów w kontekście wprowadzonych zmian dotyczyły: restrykcyjnych i nieproporcjonalnych kar, problemów natury dowodowej z przypisaniem sprawcy umyślności oraz niewystarczających konsultacji ze środowiskami prawniczymi i biznesowymi.

Warto pokreślić jeszcze jedną kwestię. Analizowana nowelizacja, dotycząca wprowadzenia nowych przestępstw przeciwko wiarygodności faktur, nie jest przykładem odosobnionym. Pokazuje pewnego rodzaju tendencję, która wskazuje na większy udział populizmu w strategiach działań ustawodawców. Równie interesującym przypadkiem może być wprowadzenie w 2017 r. instytucji konfiskaty rozszerzonej ${ }^{172}$, która pozwala na skuteczniejsze przejęcie przez Skarb Państwa korzyści uzyskanej pośrednio lub bezpośrednio w wyniku popełniania przestępstwa. Wart uwagi jest przypadek przedsiębiorstwa, który stanowi novum w polskim prawie karnym, podobnie jak przestępstwa penalizujące fałsz intelektualny w fakturach.

„Nowy populizm” penalny zaczyna oddziaływać w większym stopniu na bardziej skomplikowane problemy legislacyjne będące przedmiotem zainteresowania kilku gałęzi prawa. Nie dotyczy już tylko problemów światopoglądowych, bardziej zrozu-

170 Uzasadnienie Rządowego projektu ustawy o zmianie ustawy... (s. 2).

171 Informacja o ustawie z dnia 10 lutego 2017 r. o zmianie ustawy - Kodeks karny oraz niektórych innych ustaw, [online] http://www.prezydent.pl/prawo/ustawy/podpisane/art,19,luty-2017-r.html, 13 I 2019.

172 Zob. Ustawa z dnia 23 marca 2017 r. o zmianie ustawy - Kodeks karny oraz niektórych innych ustaw, Dz.U. 2017, poz. 768. 
miałych dla społeczeństwa, ale wpływa m.in. na regulacje dotyczące prawa karnego, gospodarczego, podatkowego itd. Społeczeństwu nadal prezentowana jest typowa populistyczna wizja przestępców okradających państwo na duże sumy, co pociąga za sobą stosowanie uproszczonych środków zaradczych w obszarach, które w sposób szczególny wymagają bardziej kompleksowej i fachowej reakcji. Pozytywną stroną tego procederu jest większe zainteresowanie społeczne danym problemem. Należy mieć nadzieję, że wpływ demagogii będzie nadal zmierzał ku „łagodnemu populizmowi”, który może pośrednio pozytywnie oddziaływać na polskie ustawodawstwo. Warunkiem tego jest wyzbycie się lub znaczące ograniczenie postulatów „twardego populizmu”, opierającego się w sposób szczególny na wysokich sankcjach karnych.

\section{BIBLIOGRAFIA}

\section{Literatura źródłowa:}

- akty prawne i ich projekty:

- Konstytucja Rzeczypospolitej Polskiej z dnia 2 kwietnia 1997 r. uchwalona przez Zgromadzenie Narodowe w dniu 2 kwietnia 1997 r., przyjęta przez Naród w referendum konstytucyjnym w dniu 25 maja 1997 r., podpisana przez Prezydenta Rzeczypospolitej Polskiej w dniu 16 lipca 1997 r., Dz.U. 1997, nr 78, poz. 483.

- Rzadowy projekt ustawy o zmianie ustawy - Kodeks karny oraz niektórych innych ustaw, druk nr 888 z 21 IX 2016 r.

- Uchwata Nr 190 Rady Ministrów z dnia 29 października 2013 r. Regulamin pracy Rady Ministrów, M.P. 2013, poz. 979.

- Ustawa z dnia 1 grudnia 2016 r. o zmianie ustawy o podatku od towarów i ustug oraz niektórych innych ustaw, Dz.U. 2016, poz. 2024.

- Ustawa z dnia 10 lutego 2017 r. o zmianie ustawy - Kodeks karny oraz niektórych innych ustaw, Dz.U. 2017, poz. 244.

- Ustawa z dnia 12 października 1990 r. o Straży Granicznej, Dz.U. 1990, nr 78, poz. 462.

- Ustawa z dnia 20 lutego 2015 r. o zmianie ustawy - Kodeks karny oraz niektórych innych ustaw, Dz.U. 2015, poz. 396.

- Ustawa z dnia 23 marca 2017 r. o zmianie ustawy - Kodeks karny oraz niektórych innych ustaw, Dz.U. 2017, poz. 768.

- Ustawa z dnia 6 czerwca 1997 r. - Kodeks karny, Dz.U. 1997, nr 88, poz. 553.

- Ustawa z dnia 6 kwietnia 1990 r. o Policji, Dz.U. 1990, nr 30, poz. 179.

- Ustawa z dnia 9 czerwca 2006 r. o Centralnym Biurze Antykorupcyjnym, Dz.U. 2006, nr 104, poz. 708 .

- dokumenty:

- Informacja o ustawie z dnia 10 lutego 2017 r. o zmianie ustawy - Kodeks karny oraz niektórych innych ustaw, [online] http://www.prezydent.pl/prawo/ustawy/podpisane/art,19,luty-2017-r.html/. 
- Najwyższa Izba Kontroli, Przeciwdziatanie wprowadzaniu do obrotu gospodarczego faktur dokumentujących czynności fikcyjne, Informacja o wynikach kontroli, nr ewid. P/15/011/ KBF, 23 III 2016 r., [online] https://www.nik.gov.pl/kontrole/P/15/011/KBF/.

- Najwyższa Izba Kontroli, Przeciwdziatanie wytudzeniom podatku VAT, Informacja o wynikach kontroli, nr ewid. 23/2018/P/17/013/KBF, 19 IV 2018 r., [online] https://www.nik. gov.pl/kontrole/P/17/013/.

- Odpowiedź Rządowego Centrum Legislacji z dnia 12 sierpnia 2016 r., RCL.DPA. 550.33/2016, [online] https://legislacja.rcl.gov.pl/projekt/12288207/katalog/12370133 \#12370133.

- Opinia Krajowej Rady Sądownictwa z dnia 16 września 2016 r. w przedmiocie projektu ustawy o zmianie ustawy - Kodeks karny oraz niektórych innych ustaw, WO 020-125/16, UD107, [online] www.krs.pl/pl/dzialalnosc/opinie-i-stanowiska/f,182,opinie-i-stanowiska-2016-r/612,12-15-wrzesnia-2016-roku/4374,opinia-krajowej-rady-sadownictwa-z-dnia-16-wrzesnia-2016-r-nr-wo-020-12516-ud107.

- Opinia z 26 października 2016 r. o projekcie ustawy o zmianie ustawy - Kodeks karny oraz niektórych innych ustaw, RL-0303-29/16, [online] https://radalegislacyjna.gov.pl/dokumenty/opinia-z-26-pazdziernika-2016-r-o-projekcie-ustawy-o-zmianie-ustawy-kodeks-karny-oraz.

- Pismo Ministerstwa Sprawiedliwości z dnia 8 września 2016 r., DL-III-400-7/16, [online] https://legislacja.rcl.gov.pl/projekt/12288207/katalog/12370166\#12370166.

- Pismo Ministerstwa Sprawiedliwości z dnia 27 lipca 2016 r., DLIII4007/16/19, [online] https://legislacja.rcl.gov.pl/projekt/12288207/katalog/12370139\#12370139.

- Posiedzenie Komisji Nadzwyczajnej do rozpatrzenia poselskiego projektu ustawy o zmianie ustawy - Kodeks karny oraz Kodeks karny wykonawczy i rzadowego projektu ustawy o postępowaniu wobec osób z zaburzeniami psychicznymi stwarzajacych zagrożenie życia, zdrowia lub wolności seksualnej innych osób, posiedzenie nr 2, 11 IX 2013 r., biuletyn nr 2315/VII, [online] http://orka.sejm.gov.pl/Zapisy7.nsf/wgskrnr/NZP-2.

- Posiedzenie Komisji Nadzwyczajnej do spraw zmian w kodyfikacjach, posiedzenie nr 28, 12 I 2017 r., biuletyn nr 1449/VIII, [online] http://orka.sejm.gov.pl/Zapisy8.nsf/wgskrnr/ NKK-28.

- Uwagi Konferencji Lewiatan z dnia 12 sierpnia 2016 r. do projektu z dnia 12 lipca 2016 r. ustawy o zmianie ustawy - Kodeks karny oraz niektórych innych ustaw, [online] https://legi slacja.rcl.gov.pl/projekt/12288207/katalog/12370139\#12370139.

- Uwagi Sądu Najwyższego z dnia 27 lipca 2016 r. do projektu ustawy o zmianie ustawy Kodeks karny i niektórych innych ustaw, BSA II 021349/16, [online] https://legislacja.rcl. gov.pl/projekt/12288207/katalog/12370145\#12370145.

- nagrania wideo:

- Nagranie z 28 posiedzenia Sejmu Rzeczpospolitej Polskiej z dnia 19 października 2016 r., pierwsze czytanie rządowego projektu ustawy o zmianie ustawy - Kodeks karny oraz niektórych innych ustaw, druk nr 888, [online] http://www.sejm.gov.pl/Sejm8.nsf/transmisje_ arch.xsp ?rok=2016\&month=10\&type=posiedzenie\#DBD8516FBAFF197FC12580 $5000453 \mathrm{FFE}$. 
- Nagraniez 34posiedzenia Sejmu Rzeczpospolitej Polskizdnia 26 stycznia 2017 r., [online] http:// www.sejm.gov.pl/Sejm8.nsf/transmisje_arch.xsp?rok=2017\&month=01\&type=posiedzenie\#724D0CA0A1A9B725C12580B3002AE24D.

- Nagranie z 35 posiedzenia Sejmu Rzeczpospolitej Polskiej z dnia 10 lutego 2017 r., Rozpatrywanie na forum Sejmu stanowiska Senatu, $w$ sprawie ustawy o zmianie ustawy Kodeks karny oraz niektórych innych ustaw, druki nr 1260 i 1262, [online] http://www.sejm. gov.pl/Sejm8.nsf/transmisje_arch.xsp?rok=2017\&month=02\&type=posiedzenie\#565A2EF69DF5C1F3C12580BF00524932.

- Nagranie z posiedzenia podkomisji statej do spraw nowelizacji prawa karnego z dnia 15 grudnia 2016 r., [online] http://www.sejm.gov.pl/Sejm8.nsf/transmisje_arch.xsp?unid=5522 EA7D25CD4BC3C125808200343E8B.

\section{Literatura pomocnicza:}

- monografie i opracowania:

- Babbie E., Badania spoteczne w praktyce, przeł. W. Betkiewicz, Warszawa 2004.

- Betz H. G., Radical Right-wing Populism in Western Europe, New York 1994.

- Dobek-Ostrowska B., Podstawy komunikowania spotecznego, Wrocław 1999.

- Ferguson A., Armstrong E., Researching Communication Disorders, Basingstoke 2009.

- Juszczyk S., Badania jakościowe w naukach spotecznych. Szkice metodologiczne, Katowice 2013.

- Morawski W., Interpretacje prawa podatkowego i celnego - stabilność i zmiana, Warszawa 2012.

- Mudde C., Syriza. The Failure of the Populist Promise, London 2017.

- Pisarek W., Analiza zawartości prasy, Kraków 1983.

- Pratt J., Penal Populism. Key Ideas in Criminology, Abingdon 2007.

- Przyłęcki P., Populizm w polskiej polityce. Analiza dyskursu polityki, Warszawa 2012.

- Roberts J. V. i in., Penal Populism and Public Opinion. Lessons from Five Countries, Oxford 2003.

- Study and Reports on the VAT Gap in the EU-28 Member States: 2018 Final Report, [online] https://ec.europa.eu/taxation_customs/business/tax-cooperation-control/vat-gap_en.

- Szafrańska M., Penalny populizm a media, Kraków 2015.

- Taggart P., Populism, Buckingham 2000.

- Taggart P., The New Populism and the New Politics. New Protest Parties in Sweden in Comparative Perspective, London 1996.

- Witkowska-Rozpara K., Przestępczość, środki masowego przekazu a polityka karna, Warszawa 2011.

- rozdziały w pracach zbiorowych:

- Albertazzi D., McDonnell D., Introduction: The Sceptre and the Spectre, [w:] D. Albertazzi, D. McDonnell, Twenty-First Century Populism. The Spectre of Western European Democracy, Basingstoke 2008.

- Canovan M., Taking Politics to the People: Populism as the Ideology of Democracy, [w:] Democracies and the Populist Challenge, red. Y. Meny, Y. Surel, Londyn 2002, http://dx.doi. org/10.1057/9781403920072_2. 
- Grzegorczyk T., Pozaprocesowa kontrola rozmów jako legalne wkraczanie w sferę konstytucyjnie chronionej wolności i tajemnicy komunikowania się, po zmianie przepisów w tej materii w 2011 r., [w:] Państwo prawa i prawo karne. Ksiega jubileuszowa Profesora Andrzeja Zolla, tom II, red. P. Kardas, T. Sroka, W. Wróbel, Warszawa 2012, [online] http://lex.adm.uj.edu. $\mathrm{pl} /$ lex/index.rpc?\&fromHistory=false\#content.rpc?nro=151225451\&wersja=-1\&.

- Lach A., Komentarz do art. 270(a) Kodeksu karnego, [w:] Kodeks Karny. Komentarz, red. V. Wrzosek-Konarska, A. Lach, J. Lachowski, [online] http://lex.adm.uj.edu.pl/ lex $/$ index.rpc? \&fromHistory=false\#content.rpc? nro $=201337380 \&$ wersja $=1 \&$ localNro Part $=587773775$.

- Lach A., Komentarz do art. 277(a) Kodeksu karnego, [w:] Kodeks Karny. Komentarz, red. V. Wrzosek-Konarska, A. Lach, J. Lachowski, [online] http://lex.adm.uj.edu.pl/lex/ index.rpc?\&fromHistory=false\# content.rpcASKnro=201337380\&wersja=1 \&localNroPart $=587773784 \&$ reqId $=1546541474589 \_1209043793 \&$ class $=$ CONTENT $\&$ loc $=4 \&$ full $=1 \& \mathrm{hId}=8$.

- Laclau E., Populism: What's in a Name?, [w:] Populism and the Mirror of Democracy, red. F. Panizza, London-New York 2005.

- Mazzoleni G., Populism and the Media, [w:] Twenty-First Century Populism. The Spectre of Western European Democracy, red. D. Albertazzi, D. McDonnell, Basingstoke 2008.

- Meny Y., Surel Y., The Constitutive Ambiguity of Populism, [w:] Democracies and the Populist Challenge, red. Y. Meny, Y. Surel, London 2002.

- Mouffe C., The „End of Politics” and the Challenge of Right-wing Populism, [w:] Populism and the Mirror of Democracy, red. F. Panizza, London-New York 2005.

- Mozgawa M., Komentarz aktualizowany do art. 271(a) Kodeksu karnego, [w:] Kodeks karny. Komentarz aktualizowany, red. M. Mozgawa, M. Budyń-Kulik, M. Kozłowska-Kalisz, [online] http://lex.adm.uj.edu.pl/lex/index.rpc?\&fromHistory=false\#content.rpc?nro= 201337332 \&wersja $=-1$ \&localNroPart $=587763147$.

- Ostrowski Ł., Tak kończa bandyci: obraz kary kryminalnej w publikacjach dziennika „Fakt”, [w:] Kulturowe uwarunkowania polityki kryminalnej, red. M. Filar, J. Utrat-Milecki, Warszawa 2014.

- Panizza F., Introduction: Populism and the Mirror of Democracy, [w:] Populism and the Mirror of Democracy, red. F. Panizza, London-New York 2005.

- Pasquino G., Populism and Democracy, [w:] Twenty-First Century Populism. The Spectre of Western European Democracy, red. D. Albertazzi, D. McDonnell, Basingstoke 2008.

- Plebanek E., Opolskim populizmie penalnym w zwiazku z obywatelskim projektem nowelizacji ustawy o planowaniu rodziny, ochronie ptodu ludzkiego i warunkach dopuszczalności przerywania ciąży oraz kodeksu karnego z 2016 r., [w:] Populizm penalny, red. J. Widacki, Kraków 2017.

- Rybicka J., Populizm penalny w dyskursie politycznym, [w:] Penalny populizm. Perspektywa polityczna i spoteczna, red. J. Czapska, M. Szafrańska, D. Wójcik, Kraków 2016.

- Sroka T., Komentarz do art. 270(a) Kodeksu karnego, [w:] Kodeks karny. Część szczególna. Tom I. Część II. Komentarz do art. 212-277d, red. W. Wróbel, A. Zoll, A. Oplustil-Barczak, [online] http://lex.adm.uj.edu.pl/lex/index.rpc?\&fromHistory=false\#content.rpc?nro= $201337243 \&$ wersja $=-1 \&$ localNroPart $=587746558$. 
- Szafrańska M., „Kończy się raj dla pedofilów!”. Populizm penalny na przyktadzie ustawo o przeciwdziataniu zagrożeniom przestępczościa na tle seksualnym, [w:] Populizm penalny, red. J. Widacki, Kraków 2017.

- Widacki J., Zamiast wstępu. Czym jest i do czego stuży populizm penalny, [w:] Populizm penalny, red. J. Widacki, Kraków 2017.

- Wróbel W., Sroka T., Komentarz do art. 270 Kodeksu karnego, [w:] Kodeks karny. Część szczególna. Tom I. Czesść II. Komentarz do art. 212-277d, red. W. Wróbel, A. Zoll, A. Oplustil-Barczak, [online] http://lex.adm.uj.edu.pl/lex/index.rpc?\&fromHistory= false\# content.rpcASKnro=201337243\&wersja = 1 \&localNroPart $=587746557 \&$ reqId $=$ 1546272744457_1710857678\&class=CONTENT\&loc $=4 \&$ full $=1 \& \mathrm{hId}=4$.

- Zgoliński I., Komentarz do art. 62 Kodeksu karnego skarbowego, [w:] Kodeks karny skarbowy. Komentarz, red. I. Zgoliński, V. Konarska-Wrzosek, J. Skorupka, [online] http://lex. adm.uj.edu.pl/lex/index.rpc\#content.rpc?nro=201337273\&wersja=1\&localNroPart $=$ 587750073.

- artykuły w czasopismach naukowych:

- Boggs C., The New Populism and the Limits of Structural Reforms, „Theory and Society” 1983, vol. 12, nr 3.

- Canovan M., Populism for Political Theorist?, „Journal of Politicial Ideologies” 2004, vol. 9, nr 3, https://doi.org/10.1080/1356931042000263500.

- Canovan M., Trust the People! Populism and the Two Faces of Democracy, „Political Studies” 1999, vol. 42, nr 1, http://dx.doi.org/10.1111/1467-9248.00184.

- Fenwick M., „Penal Populism” and Penological Change in Contemporary Japan, „Theoretical Criminology" 2013, vol. 17, nr 2, https://doi.org/10.1177/1362480613476785.

- Hawkins K. A., Is Chaves Populist. Measuring Populist Discourse in Comparative Perspective, „Comparative Political Studies” 2009, vol. 42, nr 8, https://doi.org/10.1177/ 0010414009331721.

- Jagers J., Walgrave S., Populism as Politicial Communications Style: An Empirical Study of Political Parties' Discourse in Belgium, „European Journal of Political Research” 2007, vol. 46, nr 3, https://doi.org/10.1111/j.1475-6765.2006.00690.x.

- Kann M. E., The New Populism and The New Marxism. A Response to Carl Boggs, „Theory and Society" 1983, vol. 12, nr 3.

- Kokot R., Podstawy stosowania kar wolnościowych w kodeksie karnym z 1997 r. po nowelizacji z 20 lutego 2015 r., „Nowa Kodyfikacja Prawa Karnego” 2015, t. 37.

- March L., Left and Right Populism Compared: The British Case, „The British Journal of Politics and International Relations” 2017, vol. 19, nr 2, https://doi.org/10.1177/ 1369148117701753.

- Oleson J., Habitual Criminal Legislation in New Zealand: Three Years of Three-strikes, „Australian and New Zealand Journal of Criminology” 2015, vol. 48, nr 2, https://doi. org/10.1177/0004865814532660.

- Otjes S., Louwerse T., Populists in Parliament: Comparing Left-Wing and Right-Wing Populism in the Netherlands, „Political Studies” 2015, vol.63, nr 1, https://doi.org/10.1111/ 1467-9248.12089. 
- Phillips N., Chagnon N., „Six Months Is a Joke”: Carceral Feminism and Penal Populism in the Wake of Stanford Sexual Assault Case, „Feminist Criminology” 2018, https://www.doi. org/10.1177/1557085118789782.

- Rooduijn M., What Unites the Voter Bases of Populist Parties? Comparing the Electorates of 15 Populist Parties, „European Political Science Review” 2018, vol. 10, nr 3, https://doi. org/10.1017/S1755773917000145.

- Tusalem R., Examining the Determinants of Extra-Judicial Killings in the Philippines at the Subnational Level: The Role of Penal Populism and Vertical Accountability, „Human Rights Review" 2018, vol. 19, https://doi.org/10.1007/s12142-018-0535-1.

Mateusz NOWAK, student III roku studiów doktoranckich na kierunku nauki o polityce w Katedrze Historii Współczesnej Instytutu Nauk Politycznych i Stosunków Międzynarodowych Uniwersytetu Jagiellońskiego. Interesuje się tematyką przestępczości, zwłaszcza polityką kryminalną, przestępczością gospodarczą oraz etiologią zachowań sprzecznych z prawem. 